\title{
Cost-Benefit Default Principles
}

\section{Citation}

Cass R. Sunstein, Cost-Benefit Default Principles (John M. Olin Program in Law \& Economics Working Paper No. 104, 2000).

\section{Published Version}

http://chicagounbound.uchicago.edu/law_and_economics/142/

\section{Permanent link}

http://nrs.harvard.edu/urn-3:HUL.InstRepos:12876722

\section{Terms of Use}

This article was downloaded from Harvard University's DASH repository, and is made available under the terms and conditions applicable to Other Posted Material, as set forth at http:// nrs.harvard.edu/urn-3:HUL.InstRepos:dash.current.terms-of-use\#LAA

\section{Share Your Story}

The Harvard community has made this article openly available.

Please share how this access benefits you. Submit a story.

Accessibility 


\section{University of Chicago Law School Chicago Unbound}

Coase-Sandor Working Paper Series in Law and Economics

2000

\section{Cost-Benefit Default Principles}

Cass R. Sunstein

Follow this and additional works at: http://chicagounbound.uchicago.edu/law_and_economics Part of the Law Commons

\section{Recommended Citation}

Cass R. Sunstein, "Cost-Benefit Default Principles" (John M. Olin Program in Law and Economics Working Paper No. 104, 2000).

This Working Paper is brought to you for free and open access by the Coase-Sandor Institute for Law and Economics at Chicago Unbound. It has been accepted for inclusion in Coase-Sandor Working Paper Series in Law and Economics by an authorized administrator of Chicago Unbound. For more information, please contact unbound@law.uchicago.edu. 


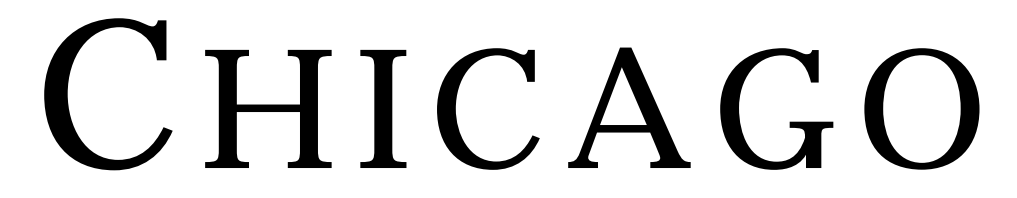

John M. Olin LAW \& ECONOMICS WORKING PAPER No. 104 (2D SERIES)

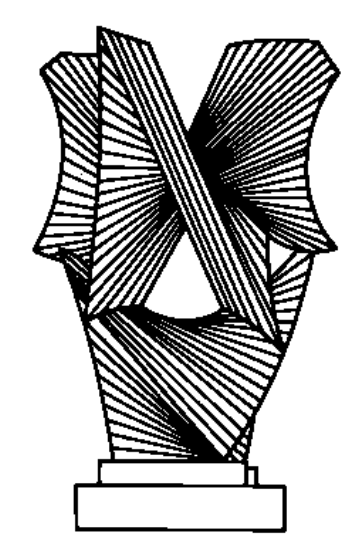

\title{
Cost-Benefit Default Principles
}

\author{
Cass R. Sunstein
}

This paper can be downloaded without charge at:

The Chicago Working Paper Series Index: http://www.law.uchicago.edu/Publications/Working/index.html

The Social Science Research Network Electronic Paper Collection: http://papers.ssrn.com/paper.taf?abstract_id=247884 


\title{
Preliminary draft 3/6/01 \\ All rights reserved
}

\section{Cost-Benefit Default Principles}

\author{
Cass R. Sunstein*
}

\begin{abstract}
In an important but thus far unnoticed development, federal courts have created a new series of "default principles" for statutory interpretation, authorizing regulatory agencies, when statutes are unclear, (a) to exempt trivial risks from regulation and thus to develop a kind of common law of "acceptable risks,"

(b) to take account of substitute risks created by regulation, and thus to engage in "health-health" tradeoffs, (c) to consider whether compliance with regulation is feasible, (d) to take costs into account, and (e) to engage in cost-benefit balancing, and thus to develop a kind of common law of cost-benefit analysis. These cost-benefit default principles are both legitimate and salutary, because they give rationality and sense the benefit of the doubt. At the same time, they leave many open questions. They do not say whether agencies are required, and not merely permitted, to go in the direction they indicate; they do not indicate when agencies might reasonably reject the principles; and they do not say what, specifically, will be counted as an "acceptable" risk or a sensible form of cost-benefit analysis. Addressing the open questions, this Article urges that the principles should ordinarily be taken as mandatory, not merely permissive; that agencies may reject them in certain identifiable circumstances; and that steps should be taken toward quantitative analysis of the effects of regulation, designed to discipline the relevant inquiries. An understanding of these points should promote understanding of emerging "second generation" debates, involving not whether to adopt a presumption in favor of cost-benefit balancing, but when the presumption is rebutted, and what, in particular, cost-benefit analysis should be taken to entail.
\end{abstract}

"Courts should be reluctant to apply the literal terms of a statute to mandate pointless expenditures of effort.... Unless Congress has been extraordinarily rigid, there is likely a basis for an implication of de minimis authority to provide exemption when the burdens of regulation yield a gain of trivial or no value." 1

"It seems bizarre that a statute intended to improve human health would ... lock the agency into looking at only one half of a substance's health effects in determining the maximum level of that substance." 2

* Karl N. Llewellyn Distinguished Service Professor, University of Chicago Law School and Department of Political Science. I am grateful to Elizabeth Garrett, Robert Hahn, Eric Posner, and Richard Posner for helpful comments on a previous draft.

${ }^{1}$ Alabama Power Co. v. Costle, 636 F.2d 323, 360-61 (DC Cir 1979).

2 American Trucking Association v. EPA, 173 F.3d 1027, 1052 (DC Cir 1999). 
"It is only where there is 'clear congressional intent to preclude consideration of cost' that we find agencies barred from considering costs." ${ }^{\prime 3}$

"In order better to achieve regulatory goals - for example, to allocate resources so that they save more lives or produce a cleaner environment - regulators must often take account of all of a proposed regulation's adverse effects, at least where those effects clearly threaten serious and disproportionate public harm. Hence, I believe that, other things being equal, we should read silences or ambiguities in the language of regulatory statutes as permitting, not forbidding, this type of rational regulation."4

“The rule-implicit valuation of a life is high - about $\$ 4$ million - but not so astronomical, certainly by regulatory standards, as to call the rationality of the rule seriously into question, especially when we consider that neither Hepatis B nor AIDS is a disease of old people. These diseases are no respecters of youth; they cut off people in their working years, and thus in their prime, and it is natural to set a high value on the lost years."

\section{Introduction}

Risks never exist in isolation. They are part of systems. For that reason, any effort to reduce a single risk will have a range of consequences, some of them likely unintended.

If the Federal Aviation Administration (FAA) increases security at airports, so as to make flying safer, it will also make flying less convenient and more expensive, and thus lead some people to drive instead. ${ }^{6}$ Flying is much safer than driving, and hence the FAA's measures might increase the number of lives lost on balance. If noise levels are reduced at the Grand Canyon, so that people can enjoy the area in peace and quiet, air tourism there will have to be dramatically reduced, so that fewer people can enjoy the area at all. ${ }^{7}$ If the Occupational Safety and Health Administration increases regulation of benzene, a carcinogenic substance, it might lead companies to use an unsafe and perhaps a less safe substitute; it might also decrease wages of affected workers, and decrease the number of jobs in the relevant industry. People who have less money, and who are unemployed, tend to live shorter lives -- and hence occupational regulation might, under certain circumstances, sacrifice more lives

\footnotetext{
${ }^{3}$ Michigan v. EPA, 213 F.3d 663, 678 (DC Cir 2000).

${ }^{4}$ Whitman v. American Trucking Associations (Feb. 27. 2001) (Breyer, J., concurring in part and concurring in the judgment).

${ }^{5}$ American Dental Association v. Martin, 984 F.2d 823, 827 (7th Cir. 1993).

6 See Robert W. Hahn, The Economics of Airline Safety, 20 Harv. . L. \& Pub. Policy 791 (1997).

${ }^{7}$ Grand Canyon Air Tour Coalition v. FAA, 154 F.3d 455 (DC Cir 1998).
} 
than it saves. ${ }^{8}$ Of course the unintended consequences of risk regulation might be desirable rather than undesirable - as, for example, where regulation spurs new pollution control technologies.

Now consider the following cases:

1. The Clean Air Act requires the Environmental Protection Agency (EPA) to issue standards controlling any substance that "contributes significantly" to pollution problems in certain areas. EPA issues regulations governing relevant pollutants, but without considering the costs of compliance. Industries challenge the regulations on the ground that cost is a statutorily relevant factor. ${ }^{9}$

2. The National Highway Traffic Safety Administration (NHTSA) is asked to promote fuel economy in automobiles "to the extent feasible." NHTSA issues fuel economy standards that are admittedly feasible, in the sense that no one doubts that they are technologically and economically possible. But the Coalition for Automobile Safety, a public interest organization, contends that the effect of the standards will be to lead manufacturers to produce smaller and more dangerous cars. The Coalition contends that NHTSA acted unlawfully in failing to take this effect into account. ${ }^{10}$

3. A federal statute requires the Occupational Safety and Health Administration to regulate toxic substances "to the extent feasible."11 OSHA interprets this language to require it to consider whether the regulation is technologically feasible and whether it is "practicable," economically speaking, for the industry to comply. OSHA imposes a regulation that is admittedly "feasible" under this test; but the statute cannot pass a cost-benefit test, because the benefits are low and the costs are high. Insisting that costs should be compared with benefits, industries subject to the regulation complain that it is unlawful. ${ }^{12}$

\footnotetext{
${ }^{8}$ See Symposium, Risk-Risk Analysis, 8 J Risk and Uncertainty 5 (1994).

${ }_{9}^{9}$ Cf. Michigan v. EPA, 213 F.3d 663, 678 (DC Cir 2000) (finding cost a permissible factor for the agency to consider under a similar statute; Lead Industries v. EPA, 647 F.2d 1130 (DC Cir 1980) (finding cost an irrelevant factor under provisions governing national ambient air quality standards).

${ }^{10}$ See Competitive Enterprise Institute v. NHTSA, 956 F.2d 321 (DC Cir. 1992).

1129 USC 655(b)(5).

${ }^{12}$ ATMI v. Donovan, 452 U.S. 490 (1981).
} 
In which of these cases has the agency acted unlawfully? The question is of immense importance, both for regulatory policy and for the relationship between courts and agencies. One of my main purposes here is to demonstrate that federal law has now built a novel set of rules for statutory construction: the cost-benefit default principles. In brief, these principles (1) allow de minimis exceptions to regulatory requirements; (2) authorize agencies to permit "acceptable" risks, departing from a requirement of "absolute" safety; (3) permit agencies to take account of both costs and feasibility; and (4) allow agencies to balance costs against benefits. Taken as a whole, the cost-benefit default principles are making a substantial difference to regulatory policy, both because of their effects in litigated cases and because of their systemic consequences for regulation. ${ }^{13}$

Even when thus specified, however, the default principles raise many questions. For the most part, the cost-benefit default principles say what agencies are permitted to do. It is not clear whether the default principles also mean that where statutes are ambiguous, agencies will be required to do any of these things. Nor do the principles give much indication of how agencies permitting "acceptable" risks, or engaging in cost-benefit analysis, might be expected to proceed. What does it mean to say that agencies are permitted to "consider" costs? Would it be unlawful for an agency to say that even very high costs are worth incurring? In what way should the monetary valuation of human life be constrained? What counts as an acceptable or de minimis risk? How should agencies deal with the interests of future generations?

However these questions are resolved, there can be no doubt that the cost-benefit default principles have emerged as a central part of what amounts to the federal common law of regulatory policy. Of course most of that common law, including the incipient federal common law of cost-benefit analysis, will emerge, and is emerging, from regulatory agencies, which have to decide how much to regulate, and why. ${ }^{14}$ Here agencies are the principal architects of what is

\footnotetext{
${ }^{13}$ See Robert Percival et al., Environmental Regulation 425 ( $4^{\text {th }}$ ed 2000). I discuss the relevance of the important decision in Whitman v. American Trucking Associations, S. Ct. (Feb. 28, 2001), below.

${ }^{14}$ Hence, for example, different agencies have come up with different dollar figures by which to value statistical lives; this is a central part of agency-made common law of cost-benefit analysis. See the table in Matthew Adler and Eric Posner, Implementing Cost-Benefit Analysis When Preferences Are Distorted, 29 J. Legal Stud. 1105, 1146 (2000). There are also striking variations in agency selection of discount rate, that is, the treatment of costs and benefits (such as lives saved)
} 
unmistakably a form of common law. But courts will undoubtedly play an important role, ${ }^{15}$ and it is in the interaction between agencies and judges that binding law will emerge. Among my largest purposes here is to understand the nature of the cost-benefit default principles, their legitimacy, and their future content. ${ }^{16}$

There is a still more general point in the background. The steady emergence of the cost-benefit default principles signals the impending conclusion, in all branches of government, ${ }^{17}$ of a "first generation" debate over whether cost-benefit analysis is desirable. ${ }^{18}$ That debate appears to be terminating with a general victory for its proponents, in the form of a presumption in favor of their view (signaled above all, perhaps, by President Clinton's substantial endorsement of cost-benefit balancing via Executive Order ${ }^{19}$ ). The "second generation" debates raise difficult questions about how (not whether) to engage in cost-benefit analysis - how to value life and health, how to deal with the interests of future generations, how to generate rules of thumb to simplify complex inquiries, how to ensure that agencies do what they are supposed to do, how and when to diverge from the conclusion recommended by cost-benefit analysis, how to determine the roles of agencies and courts in contested cases. My identification and assessment of the costbenefit default principles is intended as a contribution to these "second generation" debates. An especially important "second generation" question is

in the future. See Comment, Judicial Review of Discount Rates Used in Regulatory Cost-Benefit Analysis, 65 U Chi L Rev 1333, 1364-69 (1998) (documenting variations ranging from 2\% to 10\%). These issues are treated below.

${ }^{15}$ See, e.g., Corrosion Proof Fittings v. EPA, 947 F.2d 1201 (5 ${ }^{\text {th }}$ Cir. 1991) (striking down agency regulation of asbestos under statute calling for cost-benefit balancing).

${ }^{16}$ It is important to see that many federal agencies do not comply with the apparent requirements of cost-benefit balancing in existing executive orders. Robert Hahn has shown that compliance is episodic and that a great deal needs to be done to systematize the process. See Robert W. Hahn et al., Empirical Analysis: Assessing Regulatory Impact Analysis: The Failure of Agencies To Comply With Executive Order 12866, 23 Harv J. L \& PP 859 (2000). Here as elsewhere, there is a large difference between law on the books and law in the world. I do not attempt here to address the important issue of how to ensure compliance with principles that call for attention to costs and benefits. But judicial review of agency action can serve as a partial corrective at least, ensuring that in the egregious cases, agency action will be held invalid for failure to comply with the principles. This point is discussed at several places below.

17 Within Congress, see eg, 5 USC 1532, 1535; within the executive, see note supra.

${ }_{18}$ For discussion, see Symposium, 29 J. Legal Stud. 837 (2000); Lisa Heinzerling, Regulatory Costs of Mythic Proportions, 106 Yale LJ 1981 (1998).

${ }_{19}$ See Executive Order 12866, 58 Fed Reg 51735 (1993). 
when, if ever, the presumption in favor of cost-benefit balancing is rebutted. I attempt to make a start in answering that complex question.

The Article is organized as follows. Part II traces the rise of cost-benefit default rules in federal law; it begins with the emergence of cost-benefit principles, outlines statutory formulations, and then elaborates the default rules. Part III explores the underlying considerations in some detail - what supports the use of default principles generally and these default principles in particular. In Part III, I address the general question when the presumption in favor of the principles might be rebutted. Part IV turns to the question whether agencies should be required to do what the cost-benefit default principles permit them to do. Part V deals briefly with a set of issues that an agency must address if it is going to engage in cost-benefit balancing. Part VI is a brief conclusion.

\section{Considering and Not Considering Costs}

A. From 1970s Environmentalism to the Cost-Benefit State? A Prefatory Note

I will not attempt to resolve the broad question whether cost-benefit analysis is a good idea, or whether the many recent initiatives in that direction should be approved or modified..$^{20}$ But as background to an understanding of the costbenefit default principles, a brief discussion is in order.

The rise of interest in cost-benefit balancing signals a dramatic shift from the initial stages of national risk regulation. Those stages were undergirded by might be called "1970s environmentalism," which placed a high premium on immediate responses to long-neglected problems, which emphasized the existence of problems rather than their magnitude, and which was often rooted in moral indignation directed at the behavior of those who created pollution and other risks to safety and health..$^{21}$ Defining aspects of 1970s environmentalism can be found in the apparently cost-blind national ambient air quality provisions of the Clean Air Act ${ }^{22}$ and in statutory provisions requiring "the best available technology" without an assessment of either costs or benefits. ${ }^{23}$

\footnotetext{
${ }^{20}$ For a range of perspectives, see Symposium, 29 J. Legal Stud. 837 (2000).

${ }^{21}$ See Bruce Ackerman and Richard B. Stewart, Reforming Environmental Law, 13 Colum. J. Env.

L. 171 (1988).

2242 USC 7409(b).

${ }^{23}$ See, eg, 33 USC 1311(b)(1)AA), 42 USC 7411(a)(1), 7412(d)(2), 7475(a)(4), 7502(c)(1).
} 
No one should deny that 1970 s environmentalism has done an enormous amount of good, helping to produce dramatic improvements in many domains, above all in the context of air pollution, where ambient air quality has improved for all major pollutants. ${ }^{24}$ Indeed, 1970s environmentalism appears, by most accounts, to survive cost-benefit balancing, producing aggregate benefits in the trillions of dollars, well in excess of the aggregate costs. ${ }^{25}$ EPA's own estimates suggest that as a result of the Clean Air Act, there were no less than 184,000 fewer premature deaths among people thirty years of age or older in 1990 - and also that there were 39,000 fewer cases of congestive heart failure, 89,000 fewer cases of hospital admissions for respiratory problems, 674,000 fewer cases of chronic bronchitis, and 850,000 fewer asthma attacks. ${ }^{26}$ EPA finds annual costs of air pollution control at $\$ 32$ billion, hardly a trivial number, but less than $4 \%$ of the annual benefits of $\$ 1.1$ trillion. ${ }^{27}$ Even if the EPA's own numbers show an implausibly high ratio, significant adjustments still reveal benefits far higher than costs. ${ }^{28}$

More generally, OMB has, for the last several years, engaged in a full accounting of the costs and benefits of regulation. ${ }^{29}$ In general, the report shows benefits in excess of cost. While the government's own numbers should be discounted - agency accounts may well be self-serving - at least they provide a good place to start. ${ }^{30}$ In its 2000 report, OMB finds total regulatory benefits ranging from $\$ 254$ billion to $\$ 1.8$ trillion, with total costs ranging from $\$ 146$ billion to $\$ 229$ billion, for net benefits ranging from $\$ 25$ billion to $\$ 1.65$ trillion. ${ }^{31}$ A more disaggregated picture is also encouraging. In the transportation sector, the benefits range from $\$ 84$ billion to $\$ 110$ billion, with the costs from $\$ 15$ billion to $\$ 18$ billion, for net benefits of $\$ 66$ billion to $\$ 95$ billion. ${ }^{32}$ In the net benefits range from $\$ 9$ billion to $\$ 12$ billion. Much of the uncertainty stems from uncertainty about environmental benefits and costs, producing a range from \$-73

\footnotetext{
${ }^{24}$ See Economic Analyses at EPA 455-56 (Richard Morgenstern ed. 1998); Paul Portnoy, Air Pollution Policy, in Public Policies for Environmental Protection 77, 101-105 (Paul Portnoy and Robert Stavins eds 2000).

${ }^{25} \mathrm{Id}$.

26 Portnoy, supra, at 102-03.

27 Id. at 109.

${ }^{28} \mathrm{Id}$. at 113 (showing a benefit-cost ratio of 3 to 1 ).

${ }^{29}$ Available at http://www.whitehouse.gov/omb/inforeg/index.html.

${ }^{30}$ For a good but sometimes dated overview, see Robert Hahn, What Do The Government's Own Numbers Tell Us?, in Risks, Costs, and Lives Saved (Robert Hahn ed 1995).

${ }^{31}$ Id.; see 2000 report, charts, table 4.

32 Id.
} 
billion in net benefits to over $\$ 1.5$ trillion in net benefits. ${ }^{33}$ For most government action, however, the benefits seem to exceed the costs. ${ }^{34}$ As especially good examples, consider the following regulations, all from recent years:

Table 1: Good Cost-Benefit Ratios

\begin{tabular}{|c|c|c|c|c|}
\hline Regulation & $\begin{array}{l}2000 \text { (net benefits } \\
\text { in millions of } \\
\text { dollars) }\end{array}$ & 2005 & 2010 & 2015 \\
\hline $\begin{array}{l}\text { Head impact } \\
\text { protection }\end{array}$ & $310-370$ & $1,210-1,510$ & $1,210-1,510$ & $1,210-1,510$ \\
\hline $\begin{array}{l}\text { Conservation } \\
\text { reserve program }\end{array}$ & $\$ 1100$ & $\$ 1100$ & $\$ 1100$ & $\$ 1100$ \\
\hline $\begin{array}{l}\text { Restriction on } \\
\text { sale and } \\
\text { distribution of } \\
\text { tobacco }\end{array}$ & $9,020-9820$ & $9,020-9820$ & $9,020-10,220$ & $9,020-9820$ \\
\hline $\begin{array}{l}\text { Acid rain } \\
\text { controls }\end{array}$ & $260-1900$ & $260-1900$ & $260-1900$ & $260-1900$ \\
\hline $\begin{array}{l}\text { Energy } \\
\text { conservation } \\
\text { standards for } \\
\text { refrigerators }\end{array}$ & 330 & $330-360$ & $510-580$ & $440-500$ \\
\hline $\begin{array}{l}\text { New surface } \\
\text { water treatment }\end{array}$ & $50-1,200$ & $50-1,200$ & $50-1,200$ & $50-1,200$ \\
\hline $\begin{array}{l}\text { Emission } \\
\text { standards for } \\
\text { new highway } \\
\text { heavy-duty } \\
\text { engines }\end{array}$ & 0 & $110-1200$ & $110-1200$ & $110-1200$ \\
\hline Disposal of PCBs & $136-736$ & $136-736$ & $136-736$ & $136-736$ \\
\hline $\begin{array}{l}\text { Particulates } \\
\text { standard }\end{array}$ & 0 & 0 & $\begin{array}{l}12,000- \\
113,000\end{array}$ & $\begin{array}{l}-20,000- \\
86,000\end{array}$ \\
\hline
\end{tabular}

But even though the overall picture is no cause for alarm, a closer look at federal regulatory policy shows a wide range of problems. Perhaps foremost is

${ }^{33}$ See id.

${ }^{34}$ See id., table 5. 
exceptionally poor priority-setting, with substantial resources sometimes going to small problems, and with little attention to some serious problems. ${ }^{35}$ There are also unnecessarily high costs, with no less than $\$ 400$ billion being attributable to compliance costs each year, ${ }^{36}$ including $\$ 130$ billion on environmental protection alone. ${ }^{37} \mathrm{OMB}$ 's own report shows some disturbing numbers: For the next fifteen years, OSHA's methylene chloride regulation will have annual costs of $\$ 100$ million and annual benefits of $\$ 40$ million $^{38}$; a regulation calling for roadway worker protection has benefits of $\$ 30$ million, but equivalent costs; the costbenefit ratio for airbag depowering regulation seems bad, though there is uncertainty in the data ${ }^{39}$; EPA's regulation for financial assurance for municipal solid waste landfills has monetized benefits of $\$ 0$, but costs of $\$ 100$ million, and this is expected for the next fifteen years. ${ }^{40}$ By way of general illustration, consider the following table ${ }^{41}$ all drawn from recent regulations:

Table 2: Questionable Cost-Benefit Ratios

\begin{tabular}{|l|l|l|l|l|}
\hline Regulation & $\begin{array}{l}2000 \text { (net } \\
\text { benefits in } \\
\text { millions of } \\
\text { dollars) }\end{array}$ & 2005 & 2010 & 2015 \\
\hline $\begin{array}{l}\text { Exposure to } \\
\text { methylene } \\
\text { chloride }\end{array}$ & -60 & -60 & -60 & -60 \\
\hline $\begin{array}{l}\text { Roadway } \\
\text { worker } \\
\text { protection }\end{array}$ & 0 & 0 & 0 & 0 \\
\hline $\begin{array}{l}\text { Financial } \\
\text { assurance for } \\
\text { municipal } \\
\text { solid waste } \\
\text { landfills }\end{array}$ & -100 & -100 & -100 & -100 \\
\hline
\end{tabular}

35 This is the theme of Stephen Breyer, Breaking the Vicious Circle (1995).

36 Thomas Hopkins, The Costs of Federal Regulation, 2 J Reg and Soc. Costs 5, 25 tbl. 2 (1992).

${ }^{37}$ Paul Portney and Robert Stavins, Regulatory Review of Environmental Policy, 8 J Risk and Uncertainty 111, 119 n. 1 (1995).

38 Id., table 12.

${ }^{39}$ Id.

${ }^{40} \mathrm{Id}$.

${ }^{41} \mathrm{Id}$. 


\begin{tabular}{|l|l|l|l|l|}
\hline $\begin{array}{l}\text { Pulp and } \\
\text { paper effluent } \\
\text { guidelines }\end{array}$ & -150 to 0 & -150 to 0 & -150 to 0 & -240 to 0 \\
\hline $\begin{array}{l}\text { Ozone } \\
\text { standards }\end{array}$ & 0 & -235 to 240 & -840 to 1190 & $-9,200$ to -1000 \\
\hline $\begin{array}{l}\text { Child restraint } \\
\text { system }\end{array}$ & -40 to 40 & -40 to 40 & -40 to 40 & -40 to 40 \\
\hline $\begin{array}{l}\text { Vessel } \\
\text { response } \\
\text { plans }\end{array}$ & -220 & -220 & -220 & -220 \\
\hline $\begin{array}{l}\text { Nitrogen } \\
\text { oxide } \\
\text { emission from } \\
\text { new fossil fuel } \\
\text { fired steam } \\
\text { generating } \\
\text { units }\end{array}$ & -57 to 29 & -57 to 29 & -57 to 29 & -57 to 29 \\
\hline
\end{tabular}

These figures, drawn from regulations in a single year, show a less than coherent pattern of regulation, especially when Table 1 is put together with Table 2. According to one study, better allocations of health expenditures could save, each year, 60,000 additional lives at no additional cost - and such allocations could maintain the current level of lives saved with $\$ 31$ billion in annual savings. ${ }^{42}$ The point has been dramatized by repeated demonstrations that some regulations create significant substitute risks ${ }^{43}$-- and that with cheaper, more effective tools, regulation could achieve its basic goals while saving billions of dollars. ${ }^{44}$

In these circumstances, the most attractive parts of the movement for costbenefit analysis have been rooted not in especially controversial judgments about what government ought to be doing, but instead in a more mundane search for pragmatic instruments designed to reduce the three central problems of poor priority-setting, excessively costly tools, and inattention to the unfortunate sideeffects of regulation. By drawing attention to costs and benefits, it should be

\footnotetext{
${ }^{42}$ Tammy Tengs et al., Five Hundred Life-Saving Interventions and Their Cost-Effectiveness, 15 Risk Analysis 369 (1995).

${ }^{43}$ See John Graham and Jonathan Wiener, Risk vs. Risk (1995).

${ }^{44}$ See, e.g., A. Denny Ellerman et al., Markets in Clean Air (2000); Robert Stavins, Market-Based Environmental Policies, in Public Policies for Environmental Protection, supra, at 31, 35-55.
} 
possible to spur the most obviously desirable regulations, to deter the most obviously undesirable ones, to encourage a broader view of consequences, and to promote a search for least-cost methods of achieving regulatory goals. ${ }^{45}$ Notice here that so defended, cost-benefit analysis is not only an obstacle to unjustified regulation; it should be a spur to government as well, showing that it should attend to neglected problems. If cost-benefit balancing is supported on these highly pragmatic grounds, the central question is whether that form of balancing is actually producing what can be taken as policy improvements by people with diverse views about appropriate policy.

On these counts, the record of cost-benefit analysis, at least within the EPA, is generally encouraging. ${ }^{46}$ Assessments of costs and benefits has, for example, helped produce more stringent and rapid regulation of lead in gasoline; promoted more stringent regulation of lead in drinking water; led to stronger controls on air pollution at the Grand Canyon and the Navaho Generating Station; and produced a reformulated gasoline rule that promotes stronger controls on air pollutants. ${ }^{47}$ In these areas, cost-benefit analysis, far from being only a check on regulation, has indeed spurred governmental attention to serious problems.

Cost-benefit analysis has also led to regulations that accomplish statutory goals at lower cost, or that do not devote limited private and public resources to areas where they are unlikely to do much good. With respect to asbestos, for example, an analysis of benefits and costs led the EPA to tie the phase-down schedules to the costs of substitutes, and also to exempt certain products from a flat ban. ${ }^{48}$ With respect to lead in gasoline and control of CFCs (destructive of the ozone layer), cost-benefit analysis helped promote the use of economic incentives rather than command-and-control regulation ${ }^{49}$; economic incentives are much cheaper and make more stringent regulation possible in the first place. For regulation of sludge, protection of farmworkers, water pollution regulation for the Great Lakes, and controls on organic chemicals, cost-benefit analysis helped regulators produce modifications that significantly reduced costs. ${ }^{50}$ For modern government, one of the most serious problems appears to be, not agency use of

\footnotetext{
${ }^{45}$ For many examples, see Economic Analysis at EPA (Richard Morgenstern ed. 1996).

${ }^{46}$ See id.

${ }^{47}$ See id. at 458.

${ }^{48}$ Id. at 458.

${ }^{49} \mathrm{Id}$. at 49-86; 131-169.

${ }^{50}$ Id. at 458.
} 
cost-benefit analysis, but frequent noncompliance with executive branch requirements that agencies engage in such analysis. ${ }^{51}$

Of course cost-benefit analysis is hardly uncontroversial..$^{52}$ Insofar as both costs and benefits are being measured by the economic criterion of "private willingness to pay," there are many issues. Poor people often have little ability and hence little willingness to pay; some people will be inadequately informed, and hence show unwillingness to pay for benefits that would make their lives go better ${ }^{53}$; and perhaps regulatory agencies should seek, not private willingness to pay, but public judgments, as expressed in public arenas. ${ }^{54}$ Society is not best taken as some maximizing machine, in which aggregate output is all that matters. Sometimes a regulation producing $\$ 5$ million in benefits but $\$ 6$ million in costs will be worthwhile, if those who bear the costs (perhaps representing dollar losses alone?) can do so easily, and if those who receive the benefits (perhaps representing lives and illnesses averted?) are especially needy.

In view of these problems, the strongest arguments for cost-benefit balancing are based, not only on neoclassical economics, but also on an understanding of human cognition, on democratic considerations, and on an assessment of the real-world record of such balancing..$^{55}$ Begin with cognition: People have a hard time in understanding the systemic consequences of one-shot interventions. ${ }^{56}$ Unless they are asked to seek a full accounting, they are likely to focus on small parts of problems, producing inadequate or even counterproductive solutions. ${ }^{57}$ Cost-benefit analysis is a way of producing that full accounting. Ordinary people also have difficulty in calculating probabilities, and they tend to rely on rules of thumb, or heuristics, that can lead them to make systematic errors. ${ }^{58}$ Cost-benefit analysis is a natural corrective here. Because of intense emotional reactions to

\footnotetext{
${ }^{51}$ See Hahn, supra note.

${ }^{52}$ For a general challenge to quantification, see Lisa Heinzerling, Regulatory Costs of Mythic Proportions, 106 Yale LJ 1981 (1998).

${ }^{53}$ See Adler and Posner, supra note.

${ }^{54}$ Many of these points are pressed in Elizabeth Anderson, Value in Ethics and Economics (1993).

${ }^{55} \mathrm{I}$ attempt to develop this point in Cass R. Sunstein, Cognition and Cost-Benefit Analysis, $29 \mathrm{~J}$. Legal Stud. 1059 (2000). In the same vein, see Allan Gibbard, Risk and Value, in Values At Risk 94-112 (Douglas MacLean ed 1986).

${ }^{56}$ See Dietrich Dorner, The Logic of Failure (1994).

${ }^{57}$ Id.

${ }^{58}$ Amos Tversky and Daniel Kahneman, Judgment under Uncertainty: Heurisics and Biases, in Judgment unde Uncertainty: Heuristics and Biases 3, 11 (Daniel Kahneman, Paul Slovic, and Amos Tversky eds 1982); Roger Noll and James Krier, Some Implications of Cognitive psychology for Risk regulation, 19 J. Legal Stud. 747 (1990).
} 
particular incidents, people often make mistakes in thinking about the seriousness of certain risks. ${ }^{59}$ Cost-benefit balancing should help government resist demands for regulation that are rooted in misperceptions of facts.

With respect to democracy, the case for cost-benefit analysis is strengthened by the fact that interest-groups are often able to use these cognitive problems strategically, thus fending off regulation that is desirable, or pressing for regulation when the argument on its behalf is fragile. ${ }^{60}$ Here cost-benefit analysis, taken as an input into decisions, can protect democratic processes by exposing an account of consequences to public view. With respect to pragmatic considerations, a review of the record suggests that cost-benefit balancing leads to improvements, not on any controversial view of how to value the goods at stake, but simply because such balancing leads to more stringent regulation of serious problems, less costly ways of achieving regulatory goals, and a reduction in expenditures for problems that are, by any account, relatively minor. ${ }^{61}$

None of these points suggests that cost-benefit analysis is a panacea for the problems that I have identified. Everything depends on questions of implementation, and there are also hard questions about appropriate valuation, questions to which I shall return. Sometimes respect for rights, or concerns about irreversibility, justify a rejection of cost-benefit balancing. ${ }^{62}$ The central point is that cost-benefit analysis can be seen, not as opposition to some abstraction called "regulation," and not as an endorsement of the economic approach to valuation, but as a real-world instrument, designed to ensure that the consequences of regulation are placed before relevant officials and the public as a whole, and intended to spur attention to neglected problems while at the same time ensuring that limited resources will be devoted to areas where they will do the most good. So understood, cost-benefit analysis promises to attract support from a wide range of people with diverse perspectives on contested issues - a promise realized in the apparently growing bipartisan consensus on some form of cost-benefit balancing in many domains of regulatory policy. ${ }^{63}$ An understanding of this consensus is an indispensable background for approaching the cost-benefit default principles.

\footnotetext{
${ }^{59}$ See George Loewenstein et al., Risk As Feelings (forthcoming 2001).

${ }^{60}$ See Timur Kuran and Cass R. Sunstein, Availability Cascades and Risk Regulation, 51 Stan. L.

Rev. 683 (1999).

${ }^{61}$ See Economic Analysis at EPA 455-76.

62 TVA v. Hill, 437 US 153 (1978).

${ }^{63}$ See Executive Order 12866, 58 Fed Reg 51735 (1993).
} 


\section{B. Statutory Terms}

My emphasis here will be on the relationship between these points and judgemade default rules for statutory interpretation. But judge-made rules have considerable overlap with approaches taken explicitly by Congress, in statutes governing health, safety, and the environment. In fact there is undoubtedly an interaction effect between statutes and judge-made law, with default principles emerging from statutory formulations and vice-versa. Part of the argument for the cost-benefit default principles is that they do not reflect purely judicial polcymakng; those principles fit well with explicit enactments in other areas of the law. In dealing with the role of benefits and costs, federal statutes tend to fall in the following categories. I order the statutes roughly in accordance with their treatment of cost-benefit balancing, beginning with those that most flatly reject it, and ending with those that unambiguously embrace it.

1. Flat bans on consideration of costs. Some statutes, exemplifying 1970s environmentalism, appear to forbid any consideration of cost. Perhaps the most famous example is the Delaney Clause, which for a long period prohibited food additives that "induce cancer in man or animal." ${ }^{64}$ In the face of that language, the government sought to permit additives that, while carcinogenic, created only the most miniscule risks of cancer lower risks, in fact than those that would come from eating one peanut with the FDA-permitted level of aflatoxins every 250 days, and much lower risks than come from spending about 17 hours every year in Denver (with its high elevation and radiation levels) rather than the District of Columbia. ${ }^{65}$ Nonetheless, the Delaney Clause was taken to forbid any form of balancing. ${ }^{66}$ But a far more important example comes from the most fundamental provisions of the Clean Air Act, governing national ambient air quality standards ${ }^{67}$ For a long time, the national ambient air quality standards set under that Act have been understood to be based on "public health" alone. ${ }^{68}$ The EPA's judgment is to be grounded only in benefits; the cost of compliance is irrelevant.

\footnotetext{
${ }^{64} 21$ USC 376(b)(5)(B).

${ }^{65}$ Public Citizen v. Young, 831 F.2d 1108 (DC Cir 1987).

${ }^{66} \mathrm{Id}$.

6742 USC 7409(b).

${ }^{68}$ Lead Industries v. EPA, 647 F.2d 1130 (DC Cir 1980). See also Union Electric Company v. EPA, 427 US 246 (1976) (holding that EPA may not consider economic and technological feasibility when approving or disapproving a state implementation plan). As noted, the issue is currently before the Supreme Court. See note supra.
} 
2. Significant risk requirements. An alternative formulation is to require the agency to address only "significant" or "unacceptable" risks. On this view, risks that do not reach a certain level need not and perhaps may not be addressed. This is the prevailing interpretation of the Occupational Safety and Health Act, under both the toxic substance provisions and the more general provisions of the Act. ${ }^{69}$ A requirement of a "significant risk" falls short of cost-benefit analysis in the sense that it is entirely benefitsbased; costs are irrelevant as such. Once benefits fall below a certain threshold, regulation is not required and in fact is banned..$^{70}$ Once benefits rise above that threshold, regulation is permissible, even if the benefits seem low in comparison to the costs.

3. Substitute risks and health-health tradeoffs. Some statutes require agencies to consider whether a regulation controlling one risk would, in so doing, create a substitute risk. If so, agencies are permitted to decline to regulate, or to regulate to a different point. These are clear statutory recognition of health-health tradeoffs, which arise when there are health concerns on both sides of the equation, from both more and less regulation. ${ }^{71}$ Many statutory "consideration" requirements ${ }^{72}$ have an unambiguous feature of this sort, for example by requiring agencies entrusted with reducing air pollution problems to take account as well of "non-air quality health and environmental impacts." The Toxic Substances Control Act similarly requires the EPA to take account of substitute risks. ${ }^{73}$

4. Feasibility requirements. Some statutes require agencies to regulate "to the extent feasible" or "achievable."74 These expressions are far from transparent. But as generally understood, such statutes put the focus not on benefits but solely on costs, and on costs in a particular way: They forbid an agency from regulating to a point that is neither (a) technically

\footnotetext{
69 Industrial Union Department, AFL-CIO v. API, 448 US 607 (1980); International Union, UAW v. OSHA, 37 F.3d 605 (DC Cir 1994).

${ }^{70}$ American Trucking Assn. v. EPA, 175 F.3d 1027 (DC Cir 1999), appears to endorse this view for regulation of air pollutants, on the theory that an interpretation that would allow the EPA to pick any point it chooses would violate the nondelegation doctrine.

${ }^{71}$ See John Graham and Jonathan Wiener, Risk vs. Risk (1995).

7242 USC 7429 (a) (2) (OSHA); 42 USC 300g-1(b)(4)(B) (Safe Drinking Water Act).

${ }^{73}$ Corrosion Proof Fittings v. EPA, 947 F.2d 1201 ( $5^{\text {th }}$ Cir. 1991).

${ }^{74}$ See, eg, 29 USC 655(b)(5).
} 
feasible, because the relevant control technology does not exist, nor (b) economically feasible, because the industry cannot bear the cost without significant or massive business failures. ${ }^{75}$ The line between (a) and (b), usually treated as crisp and simple, is hardly that; whether a requirement is technically feasible will usually depend on the level of resources that are devoted to it. In practice, (a) and (b) therefore overlap in practice, with (b) serving as a separate category only on those occasions when even with massive use of existing resources, the technology cannot be brought into existence. Noteworthy here is the fact that while a significant risk requirement is entirely benefits-based, a feasibility requirement looks exclusively at the cost side of the equation. Such a requirement is a "block" of excessively expensive regulation.

5. "Consideration" requirements. A large number of statutes ask agencies to "take into consideration" various factors, including cost, in addition to the principal factor to which the statute draws the agency's attention (such as clean air or water). The most common formulation, now standard, asks the agency to produce the "maximum degree of reduction" that is "achievable," after "taking into consideration [1] the cost of achieving such emission reduction, and [2] any [a] non-air quality health and environmental impacts and $[b]$ energy requirements. ${ }^{\prime 76}$ The basic idea here is that the agency is supposed to qualify the pursuit of the "maximum" achievable reduction by asking (a) whether the cost is excessive, (b) whether energy requirements would be adversely affected, and (c) whether the "maximum" requirement might create health and environmental harms by, for example, increasing water pollution though reducing air pollution. Under the Safe Drinking Water Act, EPA is similarly instructed to back away from the maximum feasible level if the benefits of the stricter standard "would not justify the costs of complying with the level."77

6. Cost-benefit requirements. Several statutes ask agencies to balance costs against benefits, mostly through a prohibition on "unreasonable risks," alongside a definition of "unreasonable" that refers to both costs and benefits. The most prominent examples are the Toxic Substances Control

\footnotetext{
75452 US 490, 508-09 (1976); ADL-CIO v, OSHA. 965 F.2d 962, 980 (11 th Cir 1992).

7642 USC 7429 (a) (2) (OSHA); 42 USC 300g-1(b)(4)(B) (Safe Drinking Water Act).

7742 USC 300g-1(b)(6).
} 
Act $^{78}$ and the Federal Insecticide, Fungicide, and Rodenticide Act. ${ }^{79}$ Here the agency is required to calculate both costs and benefits and to compare them against each other. If the costs exceed the benefits, regulation is unacceptable. More recently, cost-benefit analysis is mandated by the Safe Drinking Water Act Amendments. ${ }^{80}$ While Congress has thus far resisted efforts to impose a cost-benefit "supermandate" calling for a general decision rule based on cost-benefit balancing, ${ }^{81}$ Congress has enacted legislation requiring assessment, and public disclosure, of costs and benefits of major regulations. ${ }^{82} \mathrm{OMB}$ itself has been required to produce annual accounting of costs and benefits..$^{83}$

In the abstract, the distinctions among these kinds of provisions should be clear enough. A statute that calls for consideration of substitute risks does not require cost-benefit balancing, because it is more narrowly concerned to ensure that risks (generally to health) do not increase on balance; under a statute calling for health-health tradeoffs, it is irrelevant that costs as such exceed benefits. A statute that requires that regulations be "feasible" is ordinarily taken to entail no comparison between costs and benefits, but a cost-focused inquiry into what industry is able to do -- whereas a statute that regulates "significant risks" is ordinarily taken to entail no comparison between costs and benefits, but a benefit-centered inquiry into the magnitude of the risk to be addressed.

Of course many open questions remain, and I will return to those questions in Part IV. Let us simply take this menu of options as the background for understanding the nature of the cost-benefit default rules.

\section{The Default Rules Identified: An Overview}

If Congress has been genuinely clear, the legal issue is at an end. But statutory terms are frequently ambiguous (this is an initial difficulty), and sometimes an interpretive problem is created by general language that seems not to reflect

\footnotetext{
7815 USC 2605 (a).

797 USC 136a(a).

8042 USC 300g-1(b)(3).

${ }^{81}$ See Cass R. Sunstein, Congress, Constitutional Moments, and the Cost-Benefit State, 48 Stan. L.

Rev. 247 (1996).

825 USC 1532, 1535

${ }^{83}$ See, eg, section 625 of the Treasury and General Government Appropriations Act, 1998, PL 10561; section 638(a) of the 1999 Omnibus Consolidated and Emergency Supplemental

Appropriations Act.
} 
anything like congressional consideration of the specific point at issue (this is a second difficulty). In the face of statutory uncertainty, cases provide support for each of the following principles. For some of the principles, the law is more developed than for others; but each of the principles is an identifiable part of contemporary public law.

-- Unless Congress has clearly said otherwise, agencies will be permitted to make de minimis exceptions to statutory requirements, by exempting small risks from regulatory controls. ${ }^{84}$

-- Unless Congress has clearly said otherwise, agencies will be permitted to take costs into account in issuing regulations. In its current form, this principle means that where statutes are ambiguous, agencies will have the authority to consider costs as well as benefits. ${ }^{85}$

-- Unless Congress has clearly said otherwise, agencies will be permitted to balance the health risks created by regulation against the health benefits created by regulation. ${ }^{86}$

-- Unless Congress has clearly said otherwise, agencies will be permitted to decline to regulate past the point where regulation would be economically or technologically feasible. ${ }^{87}$

-- Unless Congress has clearly said otherwise, agencies will be expected to balance costs against benefits in issuing regulations. ${ }^{88}$

Now let us explore some details.

D. De Minimis Exceptions

1. The basic idea. In a series of cases, the D.C. Circuit has developed a principle authorizing agencies to make de minimis exceptions to regulatory requirements. The initial case was Monsanto Co. v. Kennedy. ${ }^{89}$ There the agency banned acrylonitrile on the ground that it counts as a "food additive," migrating in small amounts from bottle into drinks within bottles. The FDA concluded that the ban was justified on safety grounds, a conclusion that the court found inadequately justified. But what is more important in the case is the general language with which the court remanded the case to the FDA. The court stressed

\footnotetext{
${ }^{84}$ See, e.g. Committee on Sensible Transportation, Inc. v. Dole, 826 F.2d 60 (DC Cir 1987).

85213 F. 2d 663 at XX.

86 This principle appears to underlie American Trucking Association v. EPA, 175 F.3d 1027 (1999).

${ }^{87}$ See NRDC v. EPA, 824 F.2d 1146 (DC Cir. 1987).

88956 F.2d 321 (DC Cir 1992).

89613 F.2d 947 (DC Cir 1979).
} 
that the agency had discretion to exclude a chemical from the statutory definition of food additives if "the level of migration into food ... is so negligible as to present no public health or safety concerns." 90

A related case presented the question whether the EPA was permitted to make categorical exemptions under the Prevention of Significant Deterioration program of the Clean Air Act. ${ }^{91}$ Here the court spoke in more ambitious terms, showing considerable enthusiasm for de minimis exemptions. It announced that "[c]ategorical exemptions may be permissible as an exercise of agency power, inherent in most statutory schemes, to overlook circumstances that in context may fairly be considered de minimis. It is commonplace, of course, that the law does not concern itself with trifling matters, and this principle has often found application in the administrative context. Courts should be reluctant to apply the literal terms of a statute to mandate pointless expenditures. ${ }^{\prime 92}$ In fact the court expressly connected this principle with the idea that the court should "look beyond the words to the purpose of the act" to avoid "absurd or futile results." Thus the court concluded, in its broadest statement on the point, that "most regulatory statutes, including the Clean Air Act, permit" de minimis exemptions upon an adequate factual showing. ${ }^{94}$

Here, then, is an explicit recognition of agency authority to exempt de minimis risks from regulatory controls. The authority operates as a clear statement principle, no less but also no more: Where Congress has unambiguously banned such exceptions, agencies are bound, and may not create de minimis exemptions even in compelling circumstances..$^{95}$

In the same vein, consider Sierra Club v. Department of Transportation. ${ }^{96}$ At issue there was a statutory requirement that the Secretary of Transportation refuse to approve the "use" of significant public park land unless "the program or project includes all possible planning to minimize the harm to the park ... resulting from the use." ${ }^{\prime \prime 7}$ The statutory question was whether limited commercial jet landings in an airport in the Grand Teton National Park should

\footnotetext{
${ }^{90}$ Id. at 955.

${ }^{91}$ Alabama Power Co. v. Costle, 636 F.2d 323 (DC Cir 1979).

${ }_{92} \mathrm{Id}$ at 359 .

${ }^{93} \mathrm{Id}$. at 360 n.89.

${ }^{94} \mathrm{Id}$. at 360.

${ }_{95}$ Public Citizen v. Young, 831 F.2d 1108 (DC Cir 1987).

96763 F.2d 120 (DC Cir 1985).

9749 USC 303@.
} 
qualify as a "use," in the face of a reasonable agency finding that the increase in flights would not result in a "significant" change in noise. The court found that the term "use" should be understood to authorize de minimis exceptions. ${ }^{98}$ There are many decisions in the same vein..$^{99}$

2. The OSHA variation: requiring de minimis exceptions. A noteworthy variation on the basic idea of permitting de minimis exceptions can be found in the plurality opinion in Industrial Union Department, AFL-CIO v. API, known as the Benzene Case. ${ }^{100}$ What the plurality said represents a variation on the basic idea for two reasons. First, the plurality forbids the agency to regulate trivial risks; it goes well beyond permitting the agency to create exemptions. Second, the plurality's substantive standard is phrased not in terms of de minimis exceptions to regulation, but of limiting regulation to "significant" risks, and hence prohibiting regulation of risks not shown to be "significant." The second difference might or might not be important, because it is not clear whether risks that do not qualify as "significant" should be treated as de minimis, though this does appear to be what the plurality had in mind.

The central issue in the case was whether OSHA had to show a "significant risk" in order to regulate a toxic substance (benzene in the case itself). In arguing that it did not, the government pointed to the central provision, which said (and says) that in promulgating the relevant standards, the Secretary "shall set the standard which most adequately assures, to the extent feasible, on the basis of the best available evidence, that no employee will suffer material impairment of health or functional capacity, even if such employee has regular exposure to the hazard dealt with by such standard for the period of his working life."101 The statute's general definition of occupational safety and health standards said (and says) that these are standards "reasonably necessary or appropriate to provide safe or healthful places of employment."102

\footnotetext{
${ }^{98}$ Id. at 130; the case is expressly understood in this way in Coalition on Safe Transportation v. Dole, 826 F.2d 60, 63 (DC Cir 1987).

99 See, e.g., Sierra Club v. EPA, 992 F.2d 337, 343-45 (DC Cir 1993); EDF v. EPA, 82 F3d 451 (DC Cir 1996)' Public Citizen v. FTC, 869 F.2d 1541, 1556-57 (DC Cir 1989); Ohio v. EPA 997 F.2d 1520, 1535 (DC Cir 1993) (suggesting that "the literal meaning of a statute need not be followed where the precise terms lead to absurd or futile results, or where failure to allow a de minimis exemption is contrary to the primary legislative goal").

100448 U.S. 607 (1980).

10129 USC 655(b)(5).

10229 USC 652(8).
} 
A straightforward interpretation of the statutory terms, urged by four justices on the Supreme Court, would seem to suggest that no significant risk need be shown. ${ }^{103}$ The key statutory language is the "no employee will suffer" phrase, which indicates that even if a toxic substance places only one or a few workers in jeopardy, OSHA must act to provide protection. Whatever the meaning of the obscure general definitional clause ("reasonably necessary or appropriate"), the more specific provision, dealing with toxic substances, would appear to trump any contrary indications in the more general one. Nonetheless, a plurality of the Court rejected OSHA's argument to this effect and hence rejected OSHA's interpretation of the statute.

In holding that a "significant risk" must be shown, the plurality contended that a contrary interpretation would defy common sense: "In light of the fact that there are literally thousands of substances used in the workplace that have been identified as carcinogens or suspected carcinogens, the Government's theory would give OSHA power to impose enormous costs that might produce little, if any, discernible benefits."104 Though the plurality left undecided the question whether the agency must also show a reasonable proportion between costs and benefits, it is clear, from the passage just quoted, that the "significant risk" requirement was motivated partly by the desire to ensure some kind of proportionality between benefits and costs, on the theory that the requirement serves to protect against the most egregious disproportions. ${ }^{105}$

In American Textile Manufacturers' Institute v. Donovan, ${ }^{106}$ however, the Court emphasized what it saw as the ordinary meaning of the word "feasible" in order to hold that OSHA was not required to engage in cost-benefit balancing. In the Court's view, the agency's job is to ensure that all regulated risks are "significant." Once a significant risk is shown, the agency is required to regulate to the point where compliance would no longer be "feasible," in the sense of practicable. ${ }^{107}$ The fact that a regulation violated a cost-benefit test is neither here nor there. This holding raises many questions, to which I will return. ${ }^{108}$ For the moment the key point is that the Court's interpretation of OSHA builds on the

\footnotetext{
103448 US at XX (Marshall, J., dissenting).

104448 US at 617.

$105 \mathrm{Id}$.

106452 US 490 (1981).

$107 \mathrm{Id}$. at 496.

108 See below.
} 
idea that de minimis exceptions are permitted to reach a conclusion that insignificant risks may not be regulated at all.

\section{E. Consideration of Cost}

The presumption that agencies may "consider costs" has also emerged in a series of important cases within the D.C. Circuit. Consider three examples,

At issue in Grand Canyon Air Coalition v. FAA, ${ }^{109}$ was an FAA regulation designed to reduce noise from airplanes over the Grand Canyon. The statute required "substantial restoration" of the "natural quiet," which the FAA understood to require that the Park achieve 50\% of the natural quiet at least 75\% of the day. In refusing to impose stricter controls, the FAA explained that it took into "consideration of the needs of the air tour industry." 110 From its ambiguous explanation, it appears that the FAA sought partly to protect the air tour industry as such, but mostly to protect tourists in their ability to see the Grand Canyon from the air. Not surprisingly, the FAA had been asked to impose both more strict and less strict regulation, and its decision was contested, by different parties, as both too strict and as excessively lenient.

Those challenging the rule said that the FAA's task was to ensure "substantial restoration" of the "natural quiet," and that protection of the air tour industry was a statutorily irrelevant factor. ${ }^{111}$ The court responded by invoking something like a presumption in favor of considering cost, noting that nothing in the statute "forbids the government from considering the impact of its regulation on the air tour industry." 112 The court's passage is ambiguous, but it appears to be a recognition that in the face of congressional silence, at least one kind of cost - that involving the air tour industry -- will be within agency discretion to consider. The narrowest construction of the court's opinion is that statutes should not be taken to be self-defeating, so that the FAA is permitted to conclude that a statute designed to enable people to enjoy the Grand Canyon, by reducing noise, should not be implemented with regulation so strict as to disable people from enjoying the Grand Canyon by the air. ${ }^{113}$ A broader reading is that under

109154 F.3d 45 (1998).

110 Id. at 48 .

111 Id. at 49.

112 Id.

${ }^{113}$ Careful readers will notice that whether this conclusion is necessary to prevent the statute from being self-defeating depends on how the statute's purposes are characterized: If the purpose is to reduce noise for those visiting the Grand Canyon, an interpretation that would ignore the 
ambiguous statutes, agencies will be presumed able to take into account the costs of various implementation strategies. ${ }^{114}$

Support for the broader reading comes from George Warren Corp. v. EPA, ${ }^{115}$ where domestic companies challenged the EPA's implementation of the reformulated gasoline provisions of the Clean Air Act. A central question for the EPA was how to treat foreign refiners and importers. In resolving that question, the EPA considered not only air quality benefits, but also the comments of the Department of Energy (DOE). That agency expressed concern that certain approaches could increase the price and decrease the quantity of gasoline, by making it more difficult for foreign refiners to divert production to the United States in periods of increased demand. ${ }^{116}$ The EPA took this point expressly into account in its rule. The result was an outcome more favorable to foreign refiners, and less favorable to environmental protection or domestic competitors, than EPA might otherwise have chosen. Nonetheless, the court upheld the agency's decision, emphasizing the absence of an explicit legislative ban on consideration of these economic factors. ${ }^{117}$ The court appeared to suggest that an express congressional preclusion of economic factors would be necessary in order to make them irrelevant as a matter of law.

By far the most explicit statement on point, however, comes from State of Michigan v. EPA. ${ }^{118}$ At issue there was an EPA decision to approve a state implementation plan (SIP) for the regulation of ozone. The statutory term provided that SIPs must contain provisions adequately prohibiting "any source or other type of emissions activity within the state from emitting any air pollutants in amounts which will ... contribute significantly to nonattainment in, or interfere with maintenance by, any other State with respect to any such national primary or secondary ambient air quality standard."119 At first glance, this provision might well be read as a kind of absolute ban on "significantly contributing" pollutants. But the EPA did not understand it that way. Instead the EPA reached a more subtle conclusion: The "significant contributors" would be required to reduce their ozone, but only by the amount achievable via "highly

interests of the air tour industry would not be self-defeating at all. Unfortunately there is no simple purpose to be "found" behind this statute.

114 This is how the case is read in Michigan v. EPA, 213 F.2d 663, (2000).

115159 F.2d 616 (1998).

116 Id. at 619.

117 Id. at 619-20.

118213 F.3d 663 (2000).

11942 USC 7410(a)(2)(D)9I)(I). 
cost-effective controls," ${ }^{120}$ meaning those that could produce large reductions relatively cheaply. In states with high control costs, then, relatively low reductions would be required.

Apparently because of the clarity of the statutory language on the particular point, no one in the case argued that EPA was required to balance costs against benefits before issuing regulations. Challenging the EPA's interpretation, environmental groups urged that the statute banned any consideration of costs at all. The court rejected the argument, finding no "clear congressional intent to preclude consideration of costs." 121 But the court obviously had a difficult time with the statutory terms "contribute significantly," which seem to refer to environmental damage, not to environmental damage measured in light of cost. In upholding the EPA's decision, the court insisted that significance should not "be measured in only one dimension," that of "health alone." In fact in some settings, the term "begs a consideration of costs." ${ }^{122}$ In the court's view, EPA would be unable to determine "'significance' if it may consider only health," especially in light of the fact that ozone causes adverse health effects at any level. If adverse effects exist on all levels, how can EPA possibly choose a standard without giving some weight to cost? ${ }^{123}$

But there is a serious problem for this conclusion. Taken together, the OSHA cases seem to argue in the opposite direction. As we have seen, the requirement that OSHA show a "significant" risk (a requirement imposed in the Benzene Case) has not been taken to mean that OSHA must or even may consider costs (with cost-benefit balancing apparently banned by the Cotton Dust Case). To this the court responded that in the aftermath of those cases, OSHA has itself attempted to ensure, and invariably claimed, that the costs of safety standards are "reasonably related to their benefits." 124 In any case "the most formidable obstacle" to a ban on consideration of cost "is the settled law of this circuit," 125 which requires an explicit legislative statement to preclude consideration of cost. Here, then, is an express judicial endorsement of a costbenefit default principle, permitting agencies to consider costs if they seek to do so.

\footnotetext{
120213 F.3d at 675 .

${ }^{121} \mathrm{Id}$. at 678 .

$122 \mathrm{Id}$.

123 Id.

${ }^{124}$ Id. at 677.

125213 F. 3d at 678.
} 


\section{F. Substitute Risks}

Extensive attention has recently been given to the problem of "risk-risk" or "health-health" tradeoffs, which arise when regulation of one health problem gives rise to another health problem. ${ }^{126}$ Suppose that more stringent fuel economy standards for new cars, justified partly on environmental and thus health-related grounds, would have the effect of leading automobile manufacturers to produce smaller and more dangerous cars, thus resulting in a significant loss of life in accidents. ${ }^{127}$ Is the agency entitled to take this effect into account? Or suppose that the FDA is asked to require genetically engineered foods to be labeled as such; if the labels would lead consumers to switch to less safe substitutes, such as organic foods, ${ }^{128}$ may the FDA take that effect into account? Or return to the case with which I began and suppose that the Federal Aviation Administration is asked to require children under the age of three to have their own seats in airplanes. The regulation might be urged on the ground that it would prevent a number of injuries in the air and also produce protection in the event of a crash. In the abstract, it is reasonable to think that children will be helped as a result. But suppose that a consequence of the mandatory purchase of a seat would be to lead many parents to drive rather than fly, on the ground that flying has suddenly become significantly more expensive. It is possible that the overall consequence of the proposed FAA rule would be that more children will die. Is the FAA permitted to take this effect into account?

Recent cases suggest an emerging principle of interpretation, in the form of a strong presumption in favor of permitting (and even requiring) agencies to take account of substitute risks, and hence to undertake health-health tradeoffs. In American Trucking Association, for example, it was argued that while ground-level ozone creates certain health risks, it also produces certain health benefits, above all because it provides protection against skin cancer and cataracts. ${ }^{129}$ The EPA responded that it lacked authority to consider the risks created by regulation or (to put the point slightly differently) the health benefits of an air pollutant. ${ }^{130}$

Taken on its own, the statutory text seemed to support the EPA's view, or at least to make that view a reasonable interpretation of ambiguous terms. The

\footnotetext{
${ }^{126}$ See, e.g., Symposium, 8 J. Risk and Uncertainty 5 (1994).

127 See note supra.

128 See Alan McHughen, Pandora's Picnic Basket 201-29, 232-237 (2000).

129175 F.3d at 1051.

130 Id. at $1051-52$.
} 
statute provides that ambient standards must be based on "criteria" documents, which are supposed to include "the latest scientific knowledge useful in indicating the kind and extent of all identifiable effects on public health or welfare which may be expected from the presence of such pollutant in the ambient air, in varying quantities."131 EPA urged, plausibly, that the phrase "identifiable effects" of "such pollutant" was meant to refer to the adverse effects of the "pollutant," not to its beneficial effects. But the court concluded that the statute could not be interpreted in that way. ${ }^{132}$ In a passage that suggests a strong presumption in favor of health-health tradeoffs, the court said (unconvincingly) that the statute was unambiguous, and (far more convincingly) that "EPA's interpretation fails even the reasonableness standard ...; it seems bizarre that a statute intended to improve human health would ... lock the agency into looking at only one half of a substance's health effects in determining the maximum level for that substance." ${ }^{\prime 133}$ What is most striking about this suggestion is that the court seems to have gone beyond the view that the agency is permitted to engage in health-health tradeoffs if it chooses, and to require the EPA to do so even if it would chose otherwise.

Or consider Competitive Enterprise Institute v. NHTSA, ${ }^{134}$ where the plaintiffs challenged fuel economy standards precisely on the ground that the agency had failed to take account of the adverse effects of such standards on automobile safety. In the face of an ambiguous statute, the court insisted that a full explanation was required for a decision that, in the abstract, would seem to create serious substitute risks. ${ }^{135}$ As a result of this decision, it is now the law that NHTSA must taken into account any evidence of adverse safety effects in the process of setting fuel economy standards. On remand, NHTSA confronted the evidence and concluded that the alleged effect could not be demonstrated - a conclusion that the court upheld on appeal. ${ }^{136}$ What is important for present purposes is the clear holding that the agency is permitted and even obliged to consider health-health tradeoffs in setting fuel economy standards.

\footnotetext{
13142 USC 7408(aq)(2).

132175 F.3d at 1052.

133175 F.3d at 1052.

134956 F.2d 321 (DC Cir 1992).

135 Id. at 324.

13645 F.3d 481, 484-86 (DC Cir 1995).
} 


\section{G. Feasibility}

Many statutes expressly require regulation to be "feasible."137 But what if the statute is silent or ambiguous on the question whether agencies may impose regulations beyond the point of "feasibility"? Sometimes statutes are "technology-forcing," in the sense that they require companies to innovate, and thus to do more than what current technology permits. ${ }^{138}$ Often, however, the technology that is 'forced" by statutory requirements is entirely feasible, indeed that it part of the reason that Congress requires it. In fact technology-forcing can be justified by cost-benefit principles themselves -- if the benefits of forcing technology outweigh the costs, as they sometimes do. Companies might fail to innovate with respect to pollution control simply because they do not internalize all of the benefits of the innovation. But technological innovation is sometimes neither feasible nor justified by cost-benefit principles. Because of large costs, regulation will sometimes raise serious questions from the standpoint of feasibility, in the sense that it will drive many companies out of business or require technologies that are not now and cannot soon be made available. Here the question is how to handle legislative silence.

The question arose most prominently in NRDC v. EPA, ${ }^{139}$ involving the toxic substances provision of the Clean Air Act. That provision, since substantially revised, ${ }^{140}$ required EPA to issue regulations that would provide "an ample margin of safety to protect the public health." 141 The principal question was whether cost was relevant to the EPA's judgment. On its face, the statute might seem to block any consideration of cost and indeed to require regulations that would reduce risks to zero, especially because for many toxic substances, safe thresholds simply do not exist. Alert to this point, the EPA urged that it should be allowed to take feasibility into account in setting regulations. The court accepted this conclusion by suggesting that regulations could avoid "zero risk" in two ways. First, the EPA was required to make an initial, benefits-based, costblind determination of what is "safe"; but citing the Benzene case, the court said that "safe" did not mean "risk-free."142 Thus "the Administrator's decision must be based upon an expert judgment with regard to the level of emission that will

\footnotetext{
137 See supra.

${ }^{138}$ For general discussion, see Bruce LaPierre, Technology-Forcing and Federal Environmental Protection Statutes, 62 Iowa L Rev 771 (1977).

139824 F.2d 1146 (DC Cir 1987).

${ }^{140}$ See 42 USC 7412.

141 USC

142824 F.2d at 1149 .
} 
result in an 'acceptable' risk to health." ${ }^{143}$ Of course there is a degree of arbitrariness in any particular judgment here, especially if the judgment is costblind. But the court was apparently attempting to ensure a degree of visibility and consistency in agency decisions, by ensuring that the "acceptable risk" judgment would be made publicly, and would be adhered to in a range of cases.

Second, the court said that in deciding how far to go beyond "safety," in order to provide an "ample margin," the Administrator was permitted to consider both costs and feasibility. ${ }^{144}$ It is clear that the court engrafted these ideas onto a statute that did not expressly include them. In this sense, the decision suggests an interpretive principle to the effect that a statute that is silent or ambiguous on the point will ordinarily be taken to permit the agency to take account of the feasibility of statutory commands.

\section{H. Costs and Benefits}

If the statute is ambiguous or silent on the point, will an agency be permitted to decide in accordance with cost-benefit balancing? Is an agency authorized to make such balancing the basis for decision?

1. In general. An affirmative answer was given in NRDC v. EPA ${ }^{145}$ (the same title, but not the same case, as that just discussed). At issue there was the EPA's decision whether to classify a source of fugitive emissions as "major" within the meaning of a statutory provision calling for regulation of "major emitting facilities. ${ }^{146}$ The EPA concluded that it would not add certain industrial sources, including surface coal mines, on the ground that the social and economic costs of regulation would outweigh the environmental benefits. ${ }^{147}$ The statutory language did not require cost-benefit analysis and the court emphasized that an alternative construction as not barred by statutory language and legislative history. ${ }^{148}$ Nonetheless, the court said that it would treat the agency's interpretation as permissible in the face of legislative silence.

Interpretation of OSHA has showed identical thinking. Outside of the area of toxic substances, the statute (with its opaque "reasonably necessary or

${ }^{143} \mathrm{Id}$.

144 Id. at 1150-51.

145937 F.2d 641 (DC Cir 1991).

14642 USC 7475.

147937 F.2d at 643.

${ }^{148}$ Id. at 645. 
appropriate" language) is ambiguous on whether cost-benefit analysis may be made the basis for decision. Here a prominent court went out of its way to say that OSHA is permitted to decide on the basis of cost-benefit balancing if it wishes. ${ }^{149}$ In a challenge to the agency's lockout/tagout rule, the court of appeals said that such balancing would be a permissible basis for agency decisions, and indeed seemed to suggest that this would be the court's preferred route. ${ }^{150} \mathrm{On}$ remand, the agency appeared to decline the court's invitation, choosing a test based largely on a mixture of the "significant risk" and "feasibility" requirements, a test that the court upheld. ${ }^{151}$ But the story does not end there. The agency has continued to say - perhaps to insulate itself from a court challenge that it finds a "reasonable relationship" between costs and benefits, and in its most recent pronouncement on the issue, the court treats this as an authoritative constructive of the statute. ${ }^{152}$ It remains to see whether an OSHA regulation that is said not to show such a reasonable relationship might be challenged as unlawful.

2. The TSCA wrinkle. A more aggressive ruling, with a statutory text more favorable to cost-benefit balancing, is Corrosion Proof Fittings v. EPA. ${ }^{153}$ What makes this a wrinkle is that as in the Benzene case, the court said not merely that the agency is permitted to follow an interpretive principle, but that it is required to do so. At the same time, the Corrosion Proof Fitting court's decision is the most elaborate statement to date of the emerging federal common law of costbenefit analysis.

At issue was the EPA's attempted ban on asbestos, an admittedly carcinogenic substance, under the Toxic Substances Control Act (TSCA). ${ }^{154}$ TSCA allows EPA to regulate "unreasonable risks,"155 and it therefore invites some kind of cost-benefit balancing. But the court went far beyond what the statute unambiguously invited. In addition to allowing EPA to engage in cost-benefit balancing, the court required a high degree of quantification from EPA, including explicit comparisons of the cost-benefit ratios for different degrees of

\footnotetext{
${ }^{149}$ International Union, UAW v. OSHA, 938 F.2d 1310 (DC Cir 1991).

$150 \mathrm{Id}$.

${ }^{151}$ International Union, UAW v. OSHA, 37 F.3d 605 (DC Cir 1994).

152 See Michigan v. EPA, supra note.

153947 F.2d 1201 (5 $5^{\text {th }}$ Cir. 1991).

15415 USC 2600 et seq.

155 The term appears no less than 35 times in 33 pages of the statute. See William Rodgers, The Lesson of the Owls and the Crows, 4 J Land Use \& Envtl. L. 377, 379 (1989). See, e.g., 15 SC 2605(a); 2605(c)(!).
} 
regulation, and also separate discussions of how regulation would affect different industries using asbestos. ${ }^{156}$ The court thus insisted that the EPA go beyond a comparison of "a world with no further regulation" and "a world in which no manufacture of asbestos takes place" to include as well cost-benefit comparisons under different approaches to regulation. ${ }^{157}$

At the same time, the court objected, not to the overall cost-benefit ratio, but to the cost-benefit ratios for some areas in which asbestos was to be banned: "[T]he agency's analysis results in figures as high as $\$ 74$ million per life saved. For example, the EPA states that is ban of asbestos pipe will save three lives over the next thirteen years, at a cost of \$128-277 million (343-76 million per life saved) ...; that its ban of asbestos shingle will cost $\$ 23-34$ million to save 0.32 statistical lives (\$72-106 million per life saved); that its ban of asbestos coatings will cost $\$ 460181$ million to save 2.22 lives (\$14-54 million per life saved) ..."158 With evident incredulity, the court sad that the "EPA would have this court believe that Congress . . . thought that spending \$200-300 million to save approximately seven lives (approximately $\$ 30-40$ million per life) over thirteen years is reasonable." ${ }^{159}$ All in all, this is an exceptionally aggressive use of the interpretive principle in favor of cost-benefit balancing. The court not only construes statutory text in a way that mandates such balancing, but also requires a demonstration that particular parts, and subparts, of the relevant regulation satisfy a cost-benefit inquiry. ${ }^{160}$

\section{A Note on American Trucking}

In a sense, the cost-benefit default principles were tested before the Supreme Court in Whitman v. American Trucking Associations. ${ }^{161}$ In that case, the Court was asked to say that the EPA could consider costs in setting national ambient air quality standards. The Court refused the invitation, concluding that such standards must be set without regard to cost. The Court emphasized the evident

\footnotetext{
156947 F.2d at 1205-07.

157 Id. at 1208.

158 Id. at 1209.

159 Id.

160 See also American Dental Association v. Martin, 984 F.2d 823 (7th Cir. 1993) (upholding OSHA regulations designed to protect against hepatitis and AIDS, and noting that the "rule's implicit valuation of life is high - about $\$ 4$ million - but not so astronomical certainly by regulatory standards, as to call the rationality of the rule seriously into question, especially when we consider that neither Hepatitis B nor AIDS is a disease of old people").

161113 S. Ct (2001).
} 
clarity of the statutory provision at issue, which defined national standards as those "requisite to protect the public health."162 In context, the reference to "public health" seemed to require a cost-blind judgment, based on health alone.

Does American Trucking throw the cost-benefit default principles into doubt? The simple answer is that it does not. The Court concluded that the Clean Air Act was unambiguous; it did not by any means suggest that an ambiguous statute would be taken to disallow consideration of costs. In his separate opinion, Justice Breyer was careful to say that courts "should read silences or ambiguities in the language of regulatory statutes" to permit consideration of "all of a proposed regulation's adverse effects," at leas where those effects would clearly be serious and disproportionate." 163 Justice Breyer was clearly concerned that the Court's approach would permit consideration of costs only where Congress had been explicit on the point. But at first glance, Justice Breyer's concern seems baseless. The Court was saying only that in view of the clarity of the main provision of the Clean Air Act, judges would be reluctant to find permission to consider costs elsewhere, since Congress "does not alter the fundamental details of a regulatory scheme in vague terms or ancillary provisions - it does not, one might say, hide elephants in mouseholes." ${ }^{\prime 164}$ This is a standard approach to statutory interpretation. It does not suggest that where a statute's "fundamental details" are vague, they will be interpreted to forbid consideration of cost.

But it would be possible to read the Court's opinion a bit more broadly. The Court seems to suggest that a statute should not be taken to confer broad discretionary authority on agencies: "We find it implausible that Congress would give to the EPA through these modest words the power to determine whether implementation costs should moderate national air quality standards." 165 To support the view that American Trucking is best taken to disallow agencies to interpret ambiguous statutes to allow consideration of costs, it would be necessary to make a simple, two-step argument. First: Statutes should be construed so as to give agencies less rather than more in the way of discretion. Second: A construction of a statute that would allow agencies to decide whether to consider costs significantly increases agency discretion. Now the claim here is not that a statute requiring cost-benefit analysis is itself disfavored on delegation grounds. The claim is instead that an interpretation should be disfavored if the

\footnotetext{
16242 USC 7409(b)(1).

$163113 \mathrm{~S}$ Ct at

164 Id. at

165 Id. at
} 
consequence of the interpretation would be to authorize the agency to decide whether to engage in cost-benefit balancing. If this claim is accepted, then the default rule in favor of allowing agencies to consider costs stands as repudiated.

This may be the concern that animates part of Justice Breyer's concurring opinion. Justice Breyer urges that "In order better to achieve regulatory goals for example, to allocate resources so that they save more lives or produce a cleaner environment - regulators must often take account of all of a proposed regulation's adverse effects, at least where those effects clearly threaten serious and disproportionate public harm. Hence, I believe that, other things being equal, we should read silences or ambiguities in the language of regulatory statutes as permitting, not forbidding, this type of rational regulation."166 Justice Breyer is clearly saying that in the face of statutory ambiguity, agencies should be allowed to consider costs, if only because that approach would increase the likelihood of rational regulation.

But it is most unlikely that the Court would disagree with him. Agencies are typically allowed to interpret statutory ambiguities, ${ }^{167}$ and in countless cases in which that principle is invoked, the agency exercises a great deal of discretion over basic issues of policy and principle. ${ }^{168}$ To allow an agency to decide to consider costs is not to allow it to exercise more discretion than it does in numerous cases. For reasons discussed below, I believe that agencies should ordinarily be required, not merely permitted, to take costs into account, because it is most reasonable to assume that this is what Congress sought. ${ }^{169}$ But where the statute is unclear, agencies should be authorized to seek "rational regulation"; and nothing in American Trucking suggests otherwise. This is especially so in light of the fact, emphasized by both the Court ${ }^{170}$ and Justice Breyer, ${ }^{171}$ that the Clean Air Act allows EPA to consider costs at numerous stages in the implementation process.

\footnotetext{
166 Id. at

167 See Chevron v. NRDC, discussed infra.

168 See, e.g., id.; Babbitt v. Sweet Home Chapter, 515 US 687 (1995); Young v. Community

Nutrition Institute, 476 US 974 (1986)

169 See below.

170113 S Ct at

171113 S. Ct. at
} 


\section{Underlying Considerations}

What are the foundations of the cost-benefit default principles? What is their rationale? Though the various default principles should be evaluated separately, there are common concerns in the background. We begin with statutory interpretation in general.

\section{A. Ambiguity, Absurdity, and Excessive Generality}

1. Three kinds of default principles. There is nothing new or unusual about default principles for statutory interpretation. They are ubiquitous. In fact they are inevitable. ${ }^{172}$ Language has no meaning without default principles of many kinds; everyone uses them every day. Generally such principles are agreed-upon, so much so that they do not seem to be principles at all. They are part of what it means to understand the relevant language. They need not even be identified, much less defended. But sometimes the principles are contested, or at least subject to contest, and in such cases, they must certainly be identified and defended, and the fact that they are being used is obvious to all.

We might distinguish three circumstances here.

-- The simplest cases involves genuine ambiguity, in the sense that without resort to an identifiable default principle, courts really do not know what the statutory term means. Here the default principle will operate as a tie-breaker, authorizing an agency to act when the case is otherwise in equipoise. The use of default principles is uncontroversial in such cases; without some such principles, cases cannot be decided.

-- Less simple cases involve texts that are most naturally or easily taken to forbid the agency action, but when there is nonetheless ambiguity. Here the default principles are serving as "clear statement" principles - suggesting that the statute will be understood to allow the agency to do what it seeks unless Congress expressly says otherwise. This is of course a more aggressive use of default principles, pushing statutes away from the disfavored terrain. It appears to be the law, for example, that agencies will be allowed to consider

\footnotetext{
172 For discussion from different perspectives, see William Eskridge, Dynamic Statutory Interpretation (1996); Cass R. Sunstein, Interpreting Statutes in the Regulatory State, 103 Harv. L. Rev. 415, 420-135 (1989).
} 
costs unless Congress expressly prohibits them from doing so; ${ }^{173}$ this is a clear statement principle, used not only when courts are in equipoise.

-- The third and most complex cases involves the sort of interpretive problem that might be understood to involve excessive generality. This is the kind of problem found when, for example, a statute saying "no vehicles in the park" is applied to a war memorial consisting of a tank used in World War II, ${ }^{174}$ or when a nephew who has murdered his uncle seeks to inherit under a will that has not been revoked. ${ }^{175}$ In many legal systems, courts will look behind the language of the statute to prevent an outcome that makes no sense and that could not possibly have been intended. ${ }^{176}$ This was the court's suggestion about the de minimis exception in Alabama Power, ${ }^{177}$ and the court's requirement that EPA consider health-health tradeoffs was clearly understood in similar terms, as an effort to prevent an outcome that would be "bizarre" and hence that Congress could not have wanted. ${ }^{178}$

2. Sense vs. nonsense. These are the circumstances for using default principles. ${ }^{179}$ But what is the appropriate content of such principles? This is a large question, and it makes sense to begin with established understandings.

Where meaning is not clear, many time-honored principles are designed to give sense and rationality the benefit of the doubt. An old interpretive principle, with roots in almost all legal systems, ${ }^{180}$ counsels courts to avoid "absurdity"; sometimes this principle has been taken into to override statutory language. More particular principles, of considerable current importance,

173 Michigan v. EPA, 213 F.3d 663, 678 (DC Cir 2000).

174 See H.L.A. Hart, The Concept of Law (1965).

175 See Riggs v. Palmer, 22 N.E. 188 (1889).

${ }^{176}$ See McCormick and Summers, Interpreting Statutes (199X).

177 Alabama Power Co. v. Costle, 636 F.2d 323, 360-61 (DC Cir 1979).

178 American Trucking Association v. EPA, 173 F.3d 1027, 1052 (DC Cir 1999).

${ }^{179}$ I do not explore here the choice between "intentional-mimicking" and "intentional-eliciting" default rules, a choice well elaborated in the law of contract. See Ian Ayres and Robert Gertner, Filling Gaps in Incomplete Contracts: An Economic Theory of Default Rules, 99 Yale LJ 87 (1989). In the area of statutory construction, it might be thought that courts should do what they think Congress would have done, if it had made provision on the point (a suggestion that supports the cost-benefit default rules) - and that if courts are unsure what Congress would have done, they should choose a rule that will encourage Congress to be more clear in the future (a suggestion that might argue against some of the default rules, on the ground that without them, Congress will be led to be clearer in the future). For detailed discussion, see Einer Elhauge, [two unpublished manuscripts 2000].

180 See McCormick and Summers, supra note. 
disfavor retroactivity ${ }^{181}$; require Congress to speak clearly if it seeks to create exemptions from the antitrust law; give the benefit of the doubt to Native Americans; and say that agencies will not, on their own, be taken to have the authority to apply statutes outside the territorial boundaries of the United States. ${ }^{182}$ It was probably inevitable that confronted with a wide range of regulatory enactments, courts would eventually develop a set of analogues for the regulatory state - principles that give rationality and sense the benefit of the doubt in the particular context of contemporary regulatory law. ${ }^{183}$

Each of the cost-benefit default principles is best defended on just this ground -- that they do give sense and rationality the benefit of the doubt and that Congress should not be taken to have mandated irrationality or absurdity. On this count, some of the default principles should be less controversial than others. At the very least, it seems sensible to say that agencies are permitted to ignore trivial risks and to balance the health benefits of regulation against te health costs of regulation. Where Congress has left things unclear, agencies should have discretion to move statutes away from (what they reasonably consider to be) the domain of senselessness. Notice that defended in this modest way, the costbenefit default principles combine substantive ideas about regulatory policy with institutional ones, in the form of a posture of judicial deference, allowing agencies room to maneuver. ${ }^{184}$ Because agencies are specialized in the topic at hand, and because they have a degree of political accountability, they are permitted to do what the cost-benefit default principles authorize. If agencies choose to do otherwise, there is, on the rationale as stated, nothing wrong with that.

But we should acknowledge here that it is possible to discern two different strands in the cases establishing the cost-benefit default principles. Call

\footnotetext{
${ }^{181}$ Bowen v. Georgetown Univ. Hosp., 488 US 204, 208-09 (1988).

182 See Cass R. Sunstein, Nondelegation Canons, 67 U Chi L Rev 315 (2000).

${ }_{183}$ Compare the controversial suggestion, in Richard Posner, Economic Analysis of Law $\left(5^{\text {th }}\right.$ ed. 1999), that the common law embodies principles of economic efficiency. I am suggesting a more modest point - not that courts are pursuing efficiency, economically defined, but that they are converging on a less sectarian, more modest set of ideas, allowing agencies to move in directions that can be seen as sensible from a wide variety of standpoints.

${ }^{184}$ For a powerful attack on unduly complex canons of construction and a plea for simplicity, see Adrian Vermeule. Interpretive Choice, 75 NY U L Rev 74 (2000). I do not deal here with the objection that the cost-benefit default principles make statutory interpretation too unruly. As they operate in the cases, the principles seem reasonably straightforward and not to produce undue complexity. But it is easy to imagine a situation in which these default principles coexisted with a number of others, thus making decisions unnecessarily complex.
} 
the first strand antiregulatory, and the second strand technocratic. On the antiregulatory strand, the principles are best seen as an effort to block regulation, ${ }^{185}$ perhaps on the theory that regulation is frequently illegitimate from the standpoint of liberty, perhaps on the ground that it usually does more harm than good. The antiregulatory strand links the principles with those prevailing in the discredited Lochner era, ${ }^{186}$ where courts used both constitutional and interpretive principles to limit regulation. By contrast, the technocratic strand embodies no animus against regulation as such. It is neutral on that question, assessing regulation only on the basis of what the data show. Indeed, it sees costbenefit analysis as a frequent impetus to regulation, as in the phaseouts of lead and CFCs. ${ }^{187}$ For technocrats, the impetus toward cost-benefit analysis is as much a check on insufficient regulation as it is a limitation on excessive controls.

To the extent that the cost-benefit principles are approved here, it is because and to the extent that they embody the technocratic strand, enlisting policy analysis in the service of better regulation. The antiregulatory form is illegitimate, a form of judicial hubris. But it should not be denied that both strands are playing a role in the cases. Let us now investigate some details.

B. De Minimis Exceptions and Acceptable Risks

The idea that agencies may make de minimis exceptions is an outgrowth of the old idea, de minimis non curat lex. If the risk at issue is tiny, the agency is not required to eliminate it. Much of the rationale here is a kind of implicit costbenefit balancing. If regulation occurs, both private and public resources will have to be expended in order to ensure compliance. When the benefits of regulation are trivial, the agency is permitted to refuse to regulate, on the ground that the costs are likely to outweigh any benefits. ${ }^{188}$ When the benefits of regulation are trivial, no one is likely to have anything to complain about if regulation is foregone. Those who are attempting to complain are likely to be

\footnotetext{
185 Of course there is no avoiding "regulation." What is ordinarily describe as "opposition to regulation" is in reality no such thing, but approval of that form of regulation that is embodied in principles of contract, tort, and property law. Nonregulation is not a possibility, short of anarchy. I use the terminology of "regulation" and "anti-regulation" to conform to common usage. The real opposition is to specific kinds and forms of regulation.

186 After Lochner v. New York, 198 US 45 (1908).

187 See Richard Benedict, Ozone Diplomacy 63 (1991); Cost-Benefit Analysis at EPA 77-83 (Richard Morgenstern ed. 1998); id. at 131-64

188 Alabama Power Co. v. Costle, 636 F.2d 323, 360-61 (DC Cir 1979).
} 
well-organized private groups with a self-interested agenda, unrelated to the purposes for which the statute was enacted. ${ }^{189}$

This understanding has the virtue of helping to account for the courts' otherwise puzzling refusal to allow EPA to make a de minimis exception under the color additive provisions of the Delaney Clause. ${ }^{190}$ Perhaps these decisions are best attributed to the fact that the statutory terms seem quite unambiguous. But as one court emphasized, it is unclear if significant costs are actually created by a decision to ban color additives. ${ }^{191}$ While the benefits of a ban are low, the costs are, in the particular circumstances, low as well. If the costs of regulation are trivial, perhaps a trivial gain from regulation is justified too. The general point is that trivial risks are unlikely to be worth private and public resources, they need not be controlled unless Congress has explicitly said that agencies must control them.

\section{Health-Health Tradeoffs}

In a way the idea of "health-health tradeoffs" is the simplest of all. If agencies are imposing health risks at the same time that they are protecting health, they should, at the very least, be permitted to take this fact into account. What most matters, after all, is whether risks are being reduced on balance (though distributional and equitable concerns can complicate this claim, as discussed below). Other things being equal, it is hardly desirable for government to reduce the respiratory risks of ground-level ozone if ground-level ozone also provides significant protection against cancer and cataracts. ${ }^{192}$ The agency should be permitted to ask whether this is what it should do, subject to review for reasonableness.

Now this does not mean that a sensible legislature will inevitably ask agencies to compare health risks with health benefits. Perhaps an institutional division of labor is sought, so that some agencies deal with some risks, whereas other agencies attend to others. ${ }^{193}$ It is imaginable, for example, that an agency entrusted with promoting fuel economy is not supposed to consider safety issues, which are a province of another institution. At least if the two agencies are not working at cross purposes, and are engaged in some effort at

\footnotetext{
${ }^{189}$ As plausible examples, see Monsanto Co., supra; Alabama Power Co., supra.

190 Public Citizen v. Young, 831 F.2d 1108 (DC Cir 1987).

191 Id. at 1111.

192 American Trucking Association v. EPA, 173 F.3d 1027, 1052 (DC Cir 1999).

${ }^{193}$ See Sunstein, Health-Health Tradeoffs, supra note.
} 
coordination, it is possible that this division of labor makes sense. The only claim is that when an agency is aggravating one health problem while it is resolving another, it ought to be permitted to take that factor into account unless Congress has said otherwise. In any case permission to engage in health-health balancing helps counteract the constant risk of tunnel vision on the part of regulators.

At this stage it might be asked why, to many people, health-health analysis seems so much less controversial than cost-benefit analysis. Many people seem skeptical of the idea that costs should be balanced against lives saved ${ }^{194}$; but few people are skeptical of the idea that lives saved should be balanced against lives lost. The simplest explanation is that people have a great deal of difficulty in trading off life against dollars, not only cognitively but also morally, and the very idea of ascribing an explicit monetary value to a (statistical) life remains controversial. ${ }^{195}$ When people are asked to weigh health against health, the mental operation is far less troublesome. People generally agree that agencies should attempt to save more lives on balance, rather than fewer. Note that this is a descriptive point about how people tend to think, intended to help explain what might seem to be an anomaly; it is not a normative point at all.

\section{Costs, Feasibility, and Costs vs. Benefits}

Why are agencies presumptively entitled to consider costs?. The basic idea must be that a "benefits only" approach also reflects a kind of tunnel vision, a myopic focus on only one of the variety of things that matter. Suppose, for example, that one approach to regulation would produce a certain level of air quality benefits, but do so at a cost of $\$ 800$ million - and that another competing approach would produce a very slightly lower level of air quality benefits, but do so at a cost of $\$ 150$ million. If costs can be made relevant, the agency is permitted

\footnotetext{
194 See, eg, Elizabeth Anderson, Value in Ethics and Economics (1993).

195 For intriguing psychological evidence, see Philip Tetlock, Taboo Tradeoffs (unpublished manuscript 2000). It might well be that the refusal to balance costs and benefits is an overgeneralization of a sound moral posture in ordinary life. In deciding whether to break a promise, or to betray a friend, we do not ordinarily balance costs against benefits, at least not in any simple or direct sense. There is a general understanding that some tradeoffs are indeed "taboo," in the sense that certain reasons for action are blocked, not merely outweighed. I speculate that the opposition to cost-benefit analysis, in government policy, is an overgeneralization of moral commitments that work well in the private domain. See Jonathan Baron, Judgment Misguided (1998).
} 
to do what seems quite sensible: to save the $\$ 650$ million on the ground that the benefits of the expenditure would not be high enough to justify the expenditure.

Of course it would be necessary to know a great deal more to know how to evaluate the particular problem. If the $\$ 650$ million would mean a significant loss of jobs, and if the lower air quality benefits would not result in significant mortality or morbidity effects, it seems most sensible not to expend the resources. But if the $\$ 650$ million would mean slightly reduced profits for producers, or slightly increased prices for a dispensable good, and if the air quality benefits would mean a nontrivial reduction in respiratory problems for tens of thousands of asthmatics, the case for more stringent regulation is far stronger. The point is not that a bare accounting of costs and benefits tells officials all of what they need to know. ${ }^{196}$ It is only that a sensible agency is entitled to, and does, "consider" the costs of regulation. Congress should not be understood to have banned agencies from doing this. If Congress has a particular reason to require otherwise, it is permitted to do exactly that.

Ideas of this sort help support the closely related idea that agencies are presumptively permitted to compare costs against benefits, and also to consider whether compliance is feasible. ${ }^{197}$ As we will see in more detail, the feasibility constraint is both ambiguous and from the normative perspective somewhat crude, because there is no identifiable point at which regulation becomes "not feasible." But a feasibility constraint, crude though it is, can be defended in the same basic way as the presumption against mandatory control of insignificant risks: If compliance is not feasible, there is a good chance that regulation is not worthwhile. The least that can be said is that if regulation is so costly that it would force many companies to go out of business, with inevitable adverse effects for workers, the agency ought to have a very strong reason for imposing it.

\section{Agency Permission versus Agency Requirements}

Thus far we have seen what agencies are permitted to do, if Congress is silent on the point. But it is necessary to distinguish between cases in which an agency attempts to do what cost-benefit principles permit and cases in which an agency refuses to do what courts are permitting. We know that for the agency,

\footnotetext{
196 See Matthew Adler and Eric Posner, Yale LJ (1999) (arguing that cost-benefit analysis is only a decision procedure).

${ }^{197}$ See supra.
} 
no legal problem will arise in the first set of cases. What about the second? Might the default principles sometimes require agencies to follow a particular course?

\section{A. The Framework}

To answer this question, some brief background is in order. Chevron v. NRDC, ${ }^{198}$ the dominant case in the area, sets out the familiar two-step inquiry for judicial review of agency decisions. The first question ("step one") is whether Congress has "directly decided the precise question at issue" - more simply, whether Congress has unambiguously banned what the agency proposes to do. ${ }^{199}$ Under Chevron, agencies are generally permitted to construe ambiguous statutes as they see fit. It follows that even without a cost-benefit default principle, agencies should be permitted to consider costs so long as the statute is ambiguous on the point. When Chevron is combined with the default principle, the overall lesson is exceedingly straightforward: Agencies are permitted to consider costs when Congress has not said that they may not.

Under Chevron, however, the issue is not finished upon a finding that Congress has not directly addressed the precise question at issue. It remains to ask whether the agency's interpretation of the statute is reasonable ("step two"). ${ }^{200}$ When the American Trucking Association court held that the EPA was required to consider the benefits as well as the risks of a pollutant, it did so partly on the ground that the agency's interpretation to the contrary was not reasonable (because it was, in the court's view, "bizarre"201). It is therefore possible that even if an agency's decision does not violate Chevron step one (because the statute is ambiguous), it will nonetheless violate step 2, if the decision can be shown to be arbitrary or "bizarre."

\section{B. The Framework Applied}

Suppose that the agency has refused to allow a de minimis exemption, or engage in health-health comparisons, or to consider costs when the statute allows it to do so. If the agency has refused to do what the cost-benefit principles permit it to do, the analysis would proceed in the following steps.

198467 US 837 (1984).

199 Id. at 842.

$200 \mathrm{Id}$.

201173 F.3d 1027, 1052 
1. The first question would involve Chevron step one: Has EPA violated unambiguous congressional instructions, or transgressed some judgment made "directly" by Congress? At first glance, the answer, by hypothesis, will be No. The statute is ambiguous rather than clear. The only possible response is that the cost-benefit default rule now operates as a kind of canon of construction, serving as part of the inquiry in Chevron step 1.

The argument is unquestionably adventurous, but not as much so as it might appear. Many canons of construction now work in precisely that way. ${ }^{202}$ Consider, for example, the following canons: statutes will not be understood to apply outside the territorial borders of the United States ${ }^{203}$; statutes will not be understood to apply retroactively ${ }^{204}$; statutes will not be taken to raise serious constitutional questions. ${ }^{205}$ In all these cases, agency interpretations do not prevail under Chevron step 1, not because Congress has expressed its will clearly, but because Congress is required to speak with clarity if it wishes agencies to act in the way that they seek. Perhaps the cost-benefit default principle should be understood in similar terms.

This is indeed possible, but it would require a significant stretch from existing law. The canons discussed above have a degree of longevity, indeed a straightforward justification from longstanding traditions. ${ }^{206}$ The cost-benefit default principles have not yet acquired the status of the canons of construction that operate as part of Chevron step 1. It is therefore exceedingly doubtful that an agency's refusal to proceed in the manner suggested by the cost-benefit default principles would be struck down under step $1 .{ }^{207}$

2. The second question would involve Chevron step 2: Is the agency's interpretation of the statute "reasonable"? I suggest that the foregoing considerations, supporting the default rules in general, suggest the basis for a particular presumption: The agency's interpretation is to be presumed unreasonable if it interprets the statute to fail to make de minimis exemptions, to

\footnotetext{
202 See Stephen Breyer et al., Administrative Law and Regulatory Policy XX (4 $4^{\text {th }}$ ed. 2000).

${ }^{203}$ EEOC v Arabian American Oil, 499 US 244, 248 (1991).

${ }^{204}$ Bowen v. Georgetown Univ. Hosp., 488 US 204, 208-09 (1988).

${ }^{205}$ DeBartolo v. Florida East Coast, 485 US 568 (1988).

${ }^{206}$ See Antonin Scalia, A Matter of Interpretation (1997) (defending canons if and only if they are vindicated by tradition).

${ }^{207}$ Evidence to this effect comes from International Union, UAW v. OSHA 37 F.3d 605 (DC Cir 1994) (upholding agency decision not to make cost-benefit analysis the basis for decision under a statute that, in the court's view, would have allowed to the agency to do this).
} 
disallow health-health tradeoffs, not to consider costs or feasibility, to regulate insignificant risks, or to ban cost-benefit balancing. ${ }^{208}$ Of these various possibilities, the presumption of unreasonableness is strongest when the agency is attempting to regulate a de minimis risk or refusing to consider health-health tradeoffs. In such cases, the agency's decision seems most obviously unreasonable. Why should expenditures be required for trivial risks? Why should the agency be permitted to increase overall risks? These questions do not have obvious answers.

The argument that agencies would be unreasonable to reject the other default principles is less clear. But even in such cases, any reasonable judgment will ordinarily be based on some kind of weighing of costs and benefits, and not on an inquiry into benefits alone. ${ }^{209}$ Return to Michigan v. EPA, and suppose that in some states, the costs of reducing the "significant contribution" would be exceedingly high, whereas the benefits would be low, in light of the fact that the risks associated with the relevant concentrations of ozone are not severe. If the costs would be high and the benefits low, on what rationale should be the EPA refuse even to consider the former? Here too there appears to be no good answer.

Notice that what is involved here is a presumption only, and it is rebuttable. It is possible to imagine agency explanations that would show why its view - to reject one or another of the cost-benefit default principles -- is reasonable. It is that question to which I now turn.

\section{Rebutting the Presumption}

In several contexts, Congress, as well as agencies and courts, could reasonably find the default principles inapplicable. The following catalogue is intended to identify circumstances in which agencies might sensibly decide not to go in the direction suggested by the default principles - and also in which a reasonable legislature might ban agencies from going in that direction.

1. Regulating de minimis risks: the case of low benefits and administrative difficulties. Suppose that an agency has discretion to interpret the relevant statute so as to allow exemptions of de minimis

\footnotetext{
${ }^{208}$ Not that there was no challenge to the agency's decision under Chevron step 2 in id., though the court's reasoning suggests that the challenge would have failed.

209 But see id. (upholding a significant risk/feasibility reading of the Occupational Safety and Health Act, notwithstanding a previous decision suggesting that cost-benefit balancing would have been a permissible reading).
} 
risks for (as an illustration) carcinogenic color additives in food. Suppose that the agency refuses to interpret the statute this way, because (a) the benefits of color food additives are generally low (noncarcinogenic color additives will do about as well), (b) as a matter of science, it is not always simple to distinguish between weak and strong carcinogens, and (c) a flat rule will be simpler to administer. At least at first glance, this sort of explanation seems fully reasonable. It would distinguish the case from one in which the agency attempts to interpret the OSHA statute in such a way as to call for costly regulation of insignificant risks.

2. Regulating risks that might or might not be de minimis: the case of scientific ignorance. Suppose that the agency attempts to regulate risks that (it agrees) cannot be shown to be significant. Suppose that it contends not that it will understand the statute to cover demonstrably insignificant or demonstrably de minimis risks, but instead to cover instead risks that, in light of existing scientific information, might be small but might be large -- a distinction that cannot be made with existing tools and in light of existing scientific understandings. In other words, the agency interprets the statute to allow regulation where the benefits might be significant, but cannot be shown to be significant given existing knowledge. This, in short, is a case where there is a wide range of expected benefits, from quite low to quite high, and where science cannot choose a probable "point" along the range (not an uncommon situation; see tables 1 and 2 for examples).

This does not seem to be an unreasonable interpretation of an ambiguous statute. Certainly the agency should be required to identify the range of potential benefits, so as to ensure that the possible gains, discounted by the probability that they will be realized, is sufficient to make regulation worthwhile. It is not hard to imagine cases of this kind; table 2 provides examples here as well. The basic point is that when scientific understanding is primitive, it can be perfectly reasonable to regulate risks that might be small but might be large. Indeed, such regulation might even survive cost-benefit balancing, notwithstanding the real possibility that when more is known, the risk will turn out to be de minimis.

3. Disregarding costs at one stage of a multistage inquiry. Might it be reasonable for an agency to interpret a statute not to allow 
consideration of costs? In some cases, this would indeed be reasonable. Recall that under the Clean Air Act, the EPA is supposed to set standards at the level that, with an "adequate margin of safety," are "requisite to protect the public health." 210 At first glance it might appear quite unreasonable for the agency not to consider costs if it has the discretion to do so. Whether it is worthwhile to produce a certain level of benefits would seem to depend, at least in part, on the cost of achieving those benefits. But suppose that the EPA urges (as it has for a number of years, and as the Supreme Court has approved ${ }^{211}$ ) that costs will be considered not in setting standards in the first instance (where health is the sole consideration), but at other, later stages, in the development of state implementation plans and in insistence on deadlines for compliance. In such a system, the EPA would say that national ambient air quality standards are based only on an inquiry into issues of health, that this is a benefits-based judgment, but that the decision how and when to meet those standards, made through complex procedures at the state and federal levels, will consider costs as well as benefits.

In fact this is how the Clean Air Act now operates. ${ }^{212}$ National standards are issued in what is at least nominally a cost-blind manner, but costs emphatically and opening play a part at other stages of the process, in the design and enforcement of state implementation plans. Whether or not it is ultimately convincing, this kind of procedural defense of "health only" judgments seems at least plausible. From this it follows that even if the relevant provisions of the Clean Air Act are taken to be ambiguous, ${ }^{213}$ it would be reasonable, under Chevron step 2 , to understand national standard-setting to be cost-blind, not because cost-blindness is itself reasonable (it isn't), but because costs are taken into account at later stages of a multistage inquiry. ${ }^{214}$ Whether it would

\footnotetext{
21042 USC 7409(b).

211 Whitman v. American Trucking Associations, S. Ct. (Feb. 28, 2001)..

212 See 42 USC 7410; Portney, supra note.

${ }^{213}$ I do not believe that they are, for reasons given in Lead Industries, supra, and followed in American Trucking Association, supra.

${ }^{214}$ From this it follows that the Supreme Court properly rejected the plea for cost-consciousness in American Trucking Association, supra, not by rejecting cost-benefit default rules, but by invoking the clarity of the statutory text and the fact that taken as a whole, the system for implementing national ambient air quality standards is far from cost-blind. Of course this is not a claim that as a matter of policy, the current system is optimal. For discussion, see Marc Landy et al., The Environmental Protection Agency: Asking the Wrong Questions (2d ed. 1996).
} 
be better for costs to be considered throughout is an issue on which reasonable people can differ. This is a highly pragmatic question, on which general enthusiasm for cost-benefit balancing is not decisive.

4. Disregarding particular costs as statutorily irrelevant. There are other arenas in which costs might reasonably be disregarded; at least agencies might disregard costs of a certain kind. Suppose, for example, that the FAA concluded that the needs of the air tour industry were entitled to no weight in issuing regulations controlling noise at the Grand Canyon. Under a different administration, the FAA might believe that the statute is best understood to ensure that those who enjoy the Grand Canyon can do so with a minimum of noise -- and that the adverse effects on the air tour industry are irrelevant, even if this means that fewer people will be able to enjoy the Grand Canyon. At first glance, this is an entirely reasonable judgment. Whee Congress has been unclear, administrations and administrators might make different decisions on that question.

5. Disregarding feasibility as part of overall balancing. Is it ever reasonable for an agency to ignore the question whether regulation is feasible for the industry? Might the FAA choose to interpret an ambiguous statute so as to impose an air quality regulation that would not be feasible for the air tour industry over the Grand Canyon, so that the relevant companies could not stay in business? At first glance, feasibility seems relevant; but it is possible to imagine cases in which an agency might reasonably choose to interpret a statute to allow rules that are not feasible. The agency might believe that it is more important to reduce noise levels than to allow the continued operation of the air tour industry. When judgments of this kind are made, the agency is effectively engaging in a kind of cost-benefit balancing, one that justifies regulation that is not feasible. Of course an agency might engage in technology-forcing, though usually this approach depends on a judgment that regulation is indeed feasible, because more advanced technologies are feasible to develop.

6. Rights and irreversibility. Thus far the discussion has emphasized pragmatic or instrumental considerations. But are there contexts in which the cost-benefit default principles are inapplicable in principle? In many domains, of course, cost-benefit balancing fails to describe the operation of law; rights-based thinking often "blocks" resorts to costs, 
or at least costs of a certain kind. ${ }^{215}$ Ordinarily ideas of this sort play a role in constitutional law, ${ }^{216}$ where certain "costs" are off limits. For example, the costs undoubtedly associated with politically controversial speech are not a legitimate basis for regulating such speech. Those costs are entitled to no weight at all; it is not as if they count, but are insufficiently high.

Such thinking is not foreign to regulatory policy. The most vivid example is the Endangered Species Act, ${ }^{217}$ which forbids agency from engaging in action that would threaten members of endangered species even if a balancing test would appear to justify the action. ${ }^{218}$ In holding that the statute disallows balancing, the Court relied on what is said was the unambiguous meaning of the text. ${ }^{219}$ But as Justice Powell showed in dissent, the language was not so clear as to disallow invocation of a strong default principle, one that would justify a degree of balancing. ${ }^{220}$ Can the outcome in the case be explained in a legal system pervaded by costbenefit default principles?

Perhaps it cannot be. Perhaps the Court's decision is an anachronism, inconsistent with the more contemporary judicial enthusiasm for balancing. But there is another explanation. The Endangered Species Act is concerned with preventing genuinely irreversible losses, and at least in the context of human activities that cause extinction, perhaps the statute is best taken to be rooted in a theory of rights, one that rebuts the presumption in favor of cost-benefit balancing. Now it is possible that some kind of "meta" balancing justifies a flat prohibition on actions that would destroy members of an endangered species. Perhaps that higher form of cost-benefit balancing calls for a refusal to engage in cost-benefit balancing in particular cases. The benefits might be thought to be so high, and the costs usually so low, as to support such a prohibition, disallowing balancing each time. But this way of understanding the statute seems to misconceive its foundations, which lie in a judgment that human beings

\footnotetext{
${ }^{215}$ See the discussion of exclusionary reasons in Joseph Raz, The Morality of Freedom (1985).

216 See Richard Pildes, Why Rights Are Not Trumps, 27 J. Legal Stud. 725 (1999).

21716 USC 1531 et seq.

218 TVA v. Hill, 437 US 153 (1978).

${ }^{219} \mathrm{Id}$. at 162.

${ }^{220}$ Id. at 166 (Powell, J., dissenting).
} 
should not knowingly bring about the extinction of other species, ${ }^{221}$ at least in the absence of truly extraordinary circumstances. ${ }^{222}$

It is possible to generalize from this example. Where regulatory policy is designed to ensure against irreversible damage, or otherwise to prevent the violation of rights, the cost-benefit default principles might well be displaced. In most domains of regulatory policy, however, what is involved is not the danger of irreversible loss, but instead issues of degree, and hence the presumption remains intact.

\section{Unsettled Questions: Specifying the Principles}

The cost-benefit default principles leave many open questions. They are abstract and general. Courts have done extremely little to particularize them; agencies have done somewhat more, but they have made only a start. ${ }^{223} \mathrm{OMB}$ has set out "best practices" for agency use ${ }^{224}$; because of the importance and generally high quality of OMB's guidance, excerpts are included as an Appendix. It is here that a great deal of law will be made in the next decades. I offer a few remarks on the crucial issues.

\section{A. The Incipient Common Law of Acceptable Risks}

What makes a risk "significant" or "de minimis"? Here the law is extremely ill-developed. Perhaps we can find some agreed-upon standards for labeling a risk de minimis. If the risk is less than that created by eating a moderate number of peanuts with legally permitted aflotoxin levels, or from living in Denver rather than New York for a week every year, the case seems relatively easy. Risks of this little are the kind that people ignore each day. But how should we evaluate (say) a cancer risk, from (say) a lifetime exposure to a certain carcinogenic substance, of one in one million? One in 100,000? One in ten million? Does it matter if the exposed population is large or small?

\footnotetext{
${ }^{221}$ See Percival et al., supra note, at 1085-1089.

${ }^{222}$ In the wake of TVA v. Hill, Congress amended section 7 of the Act to establish a special committee, known as the "God Squad," to make exemptions, and thus to permit action to go forward, under extraordinary circumstances. In the decades since the amendment, no wholesale exemption has ever been granted.

${ }^{223}$ See the overview at http://www.whitehouse.gov/media/pdf/2000fedreg-report.pdf; see also the discussion of agency practice in Adler and Posner, supra note.

${ }^{224}$ Available at http://www.whitehouse.gov/omb/inforeg/riaguide.html
} 
These are the pivotal questions. For guidance, it might be noted that the International Commission on Radiological Protection recommends that environmental factors should not be allowed to cause an incremental cancer risk, for those exposed over a lifetime, of 3 in 1000 or more. ${ }^{225}$ But the practice of American agencies is highly variable, with the EPA's acceptable range varying, under different programs, from 1 in 10,000 to 1 in 1,000,000. ${ }^{226}$ In the Benzene Case, the plurality of the Supreme Court attempted to provide some clarification, making a distinction between two quantitatively different levels of risk. If the risk of getting cancer from drinking a glass of water is one in a billion, the plurality said, it could not possibly be considered significant. ${ }^{227}$ By contrast, a fatality risk of 1/1000 from regular inhalation of gasoline vapors "might well" be considered significant. ${ }^{228}$ OSHA has built on this simple idea in issuing its own regulations. Thus the agency has said that a lifetime risk of $1.64 / 1000$ will be counted as significant, whereas a lifetime risk of 0.6 in 100,000 "may be approaching a level that can be viewed as safe." 229

This is certainly a start, and in light of the Supreme Court's statements, perhaps OSHA's approach is sufficient to survive judicial scrutiny. Certainly an effort at quantification is a helpful way of clarifying the basis for the agency's decision, especially laudable in light of the slipperiness of the idea of 'significance." But many questions might be asked. In deciding whether a risk is trivial or significant, it would seem important to ask not only about the level of the risk faced by each person, but also about the size of the exposed population. ${ }^{230}$ If two people in the United States face a lifetime risk of 2/10,000, perhaps the risk should not be deemed significant in light of the fact that it is overwhelmingly likely that no fatalities will be suffered. We could easily imagine a challenge to a decision to treat such a risk as "significant" as a matter of law. ${ }^{231}$ Certainly the agency should explain any failure to take account of the small number of exposed people -- even though it would probably be reasonable, as a matter of law, for the agency to concern itself with probabilities faced by individuals, at least if it is not permitted to engage in cost-benefit balancing.

\footnotetext{
${ }^{225}$ March Sadowitz and John Graham, A Survey of Permitted Residual Cancer Risks, 6 RISKS 17 (1995).

226 Id.

227 See 448 US at 655.

${ }^{228}$ See 448 US at 655.

22952 Fed Reg 46,168, 46,234 (1987).

${ }^{230}$ Agency attention to the size of the exposed population is strongly urged in James Hamilton and W. Kip Viscusi, Calculating Risks (1999).

${ }^{231} \mathrm{Id}$.
} 
At the same time, a statistically small risk, if faced by large numbers of people, might well be deemed significant. If twenty million people face a lifetime risk of 1/200,000, one hundred people are expected to die -- far from a trivial number. We could easily imagine a challenge to an agency decision to treat the latter risk as "insignificant"; indeed that challenge should probably succeed. The point raises serious doubts about the Supreme Court plurality's confidence that a risk of one in a billion, from drinking a glass of water, could not be deemed significant. If each person drinks five glasses of water per day, and if there are 260 million Americans, the one-in-a-billion risk no longer seems so small, converted into expected annual fatalities (474.5, hardly an insignificant number). We should therefore conclude that it is at least reasonable for agencies to consider risks to be "significant," and not de minimis, if the probability is very low but the exposed population quite large. It is also reasonable to suggest that if the probability is very low but the exposed population sufficiently large, a high number of expected fatalities should require the agency to consider the risk "significant" as a matter of law.

There is an additional problem. Both OSHA and the Supreme Court seem to focus on the "lifetime" risk - that is, the risk that would come from being exposed to a substance for all of one's working life. Under OSHA, it does seem that this focus is required by the statute, at least for toxic substances, for which the relevant provision is expressly drawn in terms of lifetime exposure. ${ }^{232}$ But in the abstract, and under other provisions, we should not be focussing on the risk, of fatality or anything else, that would come from a lifetime of exposure, except to the extent that all, most, or many people actually have a lifetime of exposure. Imagine, for example, that almost all workers in the relevant industry are exposed, not for their lifetimes, but for five years or less. What risk do they face? This is the crucial question. Perhaps the risk, for them, is a small fraction of the lifetime risk. Sensible policy requires the government to reduce the risks that people actually face, not the risk that people fancifully face. When an agency has discretion, the agency should look not at lifetime risk, but at actual risk.

What all this suggests is that when agencies are asking whether risks are significant, they ought to move in the direction of setting out a range of "expected benefits," in terms of mortality, morbidity, and other relevant variables. ${ }^{233}$ These variables could be aggregated into some sort of total number,

\footnotetext{
${ }^{232}$ See 5 USC

233 This is the direction suggested in ATA v. EPA, 175 F3d 1027, 1039-1040 (1999).
} 
below which a risk would be treated as insignificant. Of course there will be a large degree of guesswork in generating the relevant numbers. Of course too there will be a degree of arbitrariness in choosing the precise point at which risks are no longer significant. But without movement in the direction of quantification, it will not be possible to produce informed, transparent, and consistent policy. ${ }^{234}$ Thus an effort to quantify the level of risk that would be deemed acceptable would replace thc current system, with its high degree of inconsistency and guesswork, with something like a common law of acceptable risks. ${ }^{235}$

\section{B. The Meaning of Feasibility: No "On-Off" Switch}

What does it mean to say that regulation must be "feasible"? In the abstract, a requirement that regulation be "feasible" might seem to invite cost-benefit balancing. In the private sector, a "feasibility study" is essentially an exercise in cost-benefit balancing. But as we have seen, a feasibility requirement involves no balancing of costs and benefits. ${ }^{236}$ It asks instead about cost-only inquiry into whether achievement of the regulatory goal is "practicable."237

Assume, for example, that a regulation would cost $\$ 800$ million, and that in the process it would save 10 lives per year; assume also that the exposed population is relatively small, so that each of the exposed workers faces a lifetime risk of well over 1 in 1000. It is easy to imagine that this regulation would be entirely feasible, in the sense that the industry would face no technical problems in meeting it, and also in the sense that it would be practicable for industry to bear the cost. But it is also easy to imagine that such a regulation would fail costbenefit analysis, in the sense that $\$ 800$ million expense would not be justified by the (relatively lower) monetized savings. If a statistical life is valued at $\$ 5$ million, for example, the benefits ( $\$ 50$ million) would be only one-eighth the cost.

But it would be wrong to think that cost-benefit analysis is more "antiregulatory" than a feasibility constraint. We can easily imagine a regulation that might not be feasible, but that might satisfy a requirement of cost-benefit balancing. Suppose, for example, that a regulation would cost $\$ 2$ billion, that industry could not bear that cost without many business failures, but that the

234 See James Hamilton and W. Kip Viscusi, Calculating Risks (1999).

235 See Sadowitz and Graham, supra note.

${ }^{236}$ ATMI v. Donovan, 452 US 490 (1981).

237 Id. 
regulation would save 5000 lives. In some cases, the cost-benefit requirement is more protective, not less protective, of intended beneficiaries of regulatory programs.

So far, perhaps, things are clear enough. But there is a problem here as well. Most important: Feasibility is not an on-off switch. Any significant increase in costs is likely to prove "not feasible" for at least some companies. As the costs increase, the number of companies for whom the regulation proves "not feasible" will increase too. In these circumstances, it seems extremely artificial to say that at a certain point, regulation becomes "not feasible." Perhaps there is a set point at which regulation, by virtue of its stringency, establishes a sudden, large-scale increase in the number of companies who cannot bear the cost of regulatory controls while continuing in business. But it is more likely that as the costs grow, the number of companies who cannot bear the cost grows too, perhaps with several specific points at which that number spikes upwards. In these circumstances, what sense is made by a "feasibility" constraint? At first glance, very little. Just as safety is not an absolute, but a matter of degree, so too for feasibility. Law that says otherwise appears to substitute a comforting but misleading formula for a serious confrontation with the issues at stake.

Perhaps there is an intelligible answer here. Perhaps Congress wants to say that for most regulations, companies must comply, unless a large number of them can show that they cannot comply and continue. And certainly this is a relatively simple inquiry in most cases. What makes little sense is the suggestion that agencies can pick a single point that is "feasible," and go to, but not beyond, that point.

In these circumstances, how can we account for the evident popularity of requirements that regulation be "feasible" or "achievable"? There are several possibilities, suggesting that the feasibility standard might be justified by reference to institutional considerations. From the standpoint of those concerned with safety and the environment, a cost-benefit standard might be thought to introduce undue opportunities for industry to stall the process, perhaps because of the prospect and actuality of judicial review. ${ }^{238}$ A requirement that regulation must be "feasible' greatly improves agency's chances in court. In fact this conclusion is well-supported by the record of agencies on appeal; no agency has

\footnotetext{
${ }^{238}$ For evidence, see Corrosion Proof Fittings v. EPA, 947 F.2d 1201 ( $5^{\text {th }}$ Cir. 1991) (invalidating asbestos ban).
} 
ever lost a challenge to the feasibility of its regulation, while cost-benefit requirements have proved troublesome for agencies in court. ${ }^{239}$

This is a point about the goals of supporters of environmental regulation. From the standpoint of Congress, there is a separate point. A statute that expressly refers to cost-benefit balancing seems to invite complaints about the decision to trade off lives for dollars; hence statutes that embody CBA are unpopular in many circles. (It is noteworthy here that none of the actual and seriously considered enactments involving cost-benefit balancing has ever set out numbers for valuing regulatory benefits.) Legislators who seek to avoid complaints about CBA, while also seeking to impose a constraint on excessive regulation, might naturally be drawn to feasibility requirements. From the standpoint of industry, perhaps "feasibility" statutes are not so troublesome if it is possible to maintain control over the agency's docket and over appropriations, so as to ensure that draconian statutes are, in practice, far less than that.

These points help explain the appeal of feasibility constraints. But they still do not tell us what such constraints mean. The best answer, not entirely satisfactory, is that a regulation becomes infeasible if it would result in significant dislocations in the industry, in the form of large numbers of business failures, substantial losses of jobs, or the equivalent. ${ }^{240}$ Ideas of this sort are qualitative, rather than quantitative, and in implementation, they leave a great deal of discretion to agencies. What might be expected in the future is a more quantitative account from agencies implementing regulations that are said to be feasible, or refusing to impose regulations said to be infeasible.

\section{Considering Costs}

What of principles (or statutes) that ask agencies to "take into consideration" costs (and other relevant factors)? Statutes of this kind typically include an "achievability" constraint as well, one that operates, in practice, in the same way as a feasibility requirement. What is added by the idea that agencies should also take costs into consideration?

\footnotetext{
${ }^{239}$ See, eg, Corrosion Proof Fittings v. EPA, 947 F.2d 1201 (5 $5^{\text {th }}$ Cir. 1991); Aqua Slide N’ Dive Corp.

240 See, eg, United Steelworkers v. Marshall, 647 F2d 1189 (5 $5^{\text {th }}$ Cir 1980); Building and Construction Trades v. OSHA, 838 F2d 1258 (DC Cir 1988); NCP v. Brock, 825 F2d 482 (DC Cir 1987.
} 
The answer seems to be that such provisions give agencies the discretion not to go to the full extent of feasibility if the costs of doing so are disproportionately high. Suppose, for example, that a regulation would cost $\$ 800$ million and that it would save 10 lives annually. Suppose too that it is entirely feasible. If the agency is permitted to take costs into consideration, presumably it is permitted to impose a less intrusive regulation, or perhaps not to regulate at all. The foregoing sentence is qualified because the idea that costs must be taken "into consideration" does not say how much weight costs must have; it does not say, by itself, to what extent agencies must treat costs as relevant to the ultimate decision. Presumably it would be unlawful for an agency to ignore costs altogether. If the agency were permitted to do this, the "consideration" requirement would be empty. At a minimum, then, the agency must discuss cost and explain its decision in light of cost. Similarly, an agency that is allowed to "consider" costs, but need not take account of feasibility, is authorized to soften regulation by selecting less expensive and also less effective means. ${ }^{241}$ Hard questions would arise if an agency authorized to "consider" costs chooses means that are much less expensive but also much less effective.

This is a procedural understanding of the "consideration" requirement, one that has precedent under other statutes. ${ }^{242}$ But is there a substantive requirement as well? Must an agency give some kind of weight to costs, in addition to discussing them? The best answer is "yes" to both questions. An agency decision would be unlawful if it gave no weight whatsoever to costs, as, for example, through the choice of a regulation that would do only trivially more good than one that would be $50 \%$ less costly. An agency decision would also be doubtful if it made costs an overriding factor as, for example, by choosing a regulation that is slightly less expensive (say, $\$ 1$ million annually) but also much less effective (say, because it would leave 30 additional deaths annually).

On this view, a requirement that an agency take costs into consideration falls short of cost-benefit analysis, in the sense that the agency is expected to give principal weight to the initially identified factor, and from there to make adjustments because of costs. An agency would run into difficulty if it transformed costs into the overriding statutory factor or if it gave costs no substantive consideration at all. These are the polar cases for administrative

\footnotetext{
${ }^{241}$ Michigan v. EPA, supra.

${ }^{242}$ Most notably the National Environmental Policy Act. See Stryker's Bay v. Karlen, 444 US 223 (1980).
} 
illegality. Cases that fall between the poles should present hard line-drawing questions, but no serious conceptual issues.

\section{Of Costs and Benefits}

It remains to discuss the largest problem of all. If cost-benefit balancing is required, what is an agency permitted to do? What is it prohibited from doing? Of course there are hard issues of valuation here. If an agency values a life at $\$ 10$ million, it will produce outcomes very different from those that would be follow if it valued a life at $\$ 500,000$. Is an agency permitted to value a life at, say, $\$ 100$ million, or at $\$ 50,000 ? 243$

1. Basic issues of valuation: the standard approach. For several decades, agencies have undertaken cost-benefit analysis of major regulations, even when cost-benefit analysis is not the basis for decision but is merely a matter of informing the public about the consequences of proposed courses of action. ${ }^{244}$ But how are costs and benefits to be calculated? In principle, the issue is often easier to resolve on the cost side, though the practical problems here can be very serious, especially in light of industry's incentive to overestimate costs. With respect to benefits, the now-standard approach involves an effort to calculate people's "willingness to pay" for the various goods at stake. ${ }^{245}$ Sophisticated (though still controversial ${ }^{246}$ ) methods are available for this purpose. ${ }^{247}$

There remains a good deal of variation across agencies, with statistical lives being valued at between $\$ 1.5$ million and $\$ 5.8$ million. ${ }^{248}$ With respect to statistical lives, consider the following table ${ }^{249}$ :

\footnotetext{
${ }^{243}$ See Corrosion Proof Fittings v. EPA, 947 F.2d 1201 (5 $5^{\text {th }}$ Cir. 1991).

${ }^{244}$ For an overview, see Richard Pildes and Cass R. Sunstein, Reconceiving the Regulatory State, 62 U Chi L Rev 1 (1995).

245 This approach is challenged in many places. See, e.g., Elizabeth Anderson, Value in Ethics and Economics (1993).

${ }^{246}$ See Markets, Mortality, and Work (1998).

247 See W. Kip Viscusi, Fatal Tradeoffs (1992).

248 See Matthew Adler and Eric Posner, supra note. EPA is generally using a number of $\$ 4.8$ million per statistical life saved. See Section 812 Retrospective (1997).

${ }^{249}$ Borrowed from Matthew Adler and Eric Posner, Implementing Cost-Benefit Analysis When Preferences Are Distorted, J. Legal Stud. (forthcoming 2000).
} 


\section{Table 3: Valuations of Life}

\begin{tabular}{|c|c|c|c|}
\hline AGENCY & REGULATION & CITATION & $\begin{array}{l}\text { VALUE } \\
\text { (\$ mil.) }\end{array}$ \\
\hline $\begin{array}{l}\text { Department of Transportation - } \\
\text { Federal Aviation Administration }\end{array}$ & $\begin{array}{l}\text { Proposed Establishment of the } \\
\text { Harlingen Airport Radar Service } \\
\text { Area, TX }\end{array}$ & $\begin{array}{l}55 \text { FR 32064 } \\
\text { August 6, } 1990\end{array}$ & 1.5 \\
\hline $\begin{array}{l}\text { Department of Agriculture - Food } \\
\text { Safety and Inspection Service }\end{array}$ & $\begin{array}{l}\text { Pathogen Reduction: Hazard } \\
\text { Analysis and Critical Control } \\
\text { Point Systems }\end{array}$ & $\begin{array}{l}61 \text { FR } 38806 \\
\text { July } 25,1996\end{array}$ & 1.6 \\
\hline $\begin{array}{l}\text { Department of Health and } \\
\text { Human Services - Food and Drug } \\
\text { Administration }\end{array}$ & $\begin{array}{l}\text { Regulations Restricting the Sale } \\
\text { and Distribution of Cigarettes } \\
\text { and Smokeless Tobacco to Protect } \\
\text { Children and Adolescents }\end{array}$ & $\begin{array}{l}61 \text { FR } 44396 \\
\text { August 28, } \\
1996\end{array}$ & 2.5 \\
\hline $\begin{array}{l}\text { Department of Transportation - } \\
\text { Federal Aviation Administration }\end{array}$ & $\begin{array}{l}\text { Aircraft Flight Simulator Use in } \\
\text { Pilot Training, Testing, and } \\
\text { Checking and at Training Centers }\end{array}$ & $\begin{array}{l}61 \text { FR } 34508 \\
\text { July } 2,1996\end{array}$ & 2.7 \\
\hline Environmental Protection Agency & Protection of Stratospheric Ozone & $\begin{array}{l}53 \text { FR } 30566 \\
\text { August 12, } \\
1988\end{array}$ & 3 \\
\hline $\begin{array}{l}\text { Department of Health and } \\
\text { Human Services - Food and Drug } \\
\text { Administration }\end{array}$ & $\begin{array}{l}\text { Proposed Rules to Amend the } \\
\text { Food Labeling Regulations }\end{array}$ & $\begin{array}{l}56 \text { FR } 60856 \\
\text { November 27, } \\
1991 \\
\end{array}$ & 3 \\
\hline $\begin{array}{l}\text { Department of Transportation - } \\
\text { Federal Aviation Administration }\end{array}$ & $\begin{array}{l}\text { Financial Responsibility } \\
\text { Requirements for Licensed } \\
\text { Launch Activities }\end{array}$ & $\begin{array}{l}61 \text { FR } 38992 \\
\text { July 25, } 1996\end{array}$ & 3 \\
\hline $\begin{array}{l}\text { Department of Agriculture - Food } \\
\text { and Nutrition Service }\end{array}$ & $\begin{array}{l}\text { Proposed National School Lunch } \\
\text { Program and School Breakfast } \\
\text { Program }\end{array}$ & $\begin{array}{l}\text { 59 FR 30218 } \\
\text { June 10, } 1994\end{array}$ & $1.5,3.0$ \\
\hline Environmental Protection Agency & $\begin{array}{l}\text { National Ambient Air Quality } \\
\text { Standards for Particulate Matter }\end{array}$ & $\begin{array}{l}62 \text { FR } 38652 \\
\text { July } 18,1997\end{array}$ & 4.8 \\
\hline Environmental Protection Agency & $\begin{array}{l}\text { National Ambient Air Quality } \\
\text { Standards for Ozone }\end{array}$ & $\begin{array}{l}62 \text { FR } 38856 \\
\text { July } 18,1996 \\
\end{array}$ & 4.8 \\
\hline $\begin{array}{l}\text { Department of Health and } \\
\text { Human Services - Food and Drug } \\
\text { Administration }\end{array}$ & $\begin{array}{l}\text { Medical Devices: Current Good } \\
\text { Manufacturing Practice }\end{array}$ & $\begin{array}{l}61 \text { FR } 52602 \\
\text { October } 7 \\
1996 \\
\end{array}$ & 5 \\
\hline $\begin{array}{l}\text { Department of Health and } \\
\text { Human Services - Public Health } \\
\text { Service, Food and Drug } \\
\text { Administration }\end{array}$ & $\begin{array}{l}\text { Quality Mammography } \\
\text { Standards }\end{array}$ & $\begin{array}{l}62 \text { FR } 55852 \\
\text { October } 28, \\
1997\end{array}$ & 5 \\
\hline Environmental Protection Agency & $\begin{array}{l}\text { Requirements for Lead-Based } \\
\text { Paint Activities in Target } \\
\text { Housing and Child-Occupied } \\
\text { Facilities }\end{array}$ & $\begin{array}{l}61 \text { FR } 45778 \\
\text { August 29, } \\
1996\end{array}$ & 5.5 \\
\hline Environmental Protection Agency & $\begin{array}{l}\text { National Primary Drinking } \\
\text { Water Regulations: Disinfectants } \\
\text { and Disinfection Byproducts }\end{array}$ & $\begin{array}{l}63 \text { FR } 69390 \\
\text { December 16, } \\
1998\end{array}$ & 5.6 \\
\hline Environmental Protection Agency & $\begin{array}{l}\text { Radon in Drinking Water Health } \\
\text { Risk Reduction and Cost } \\
\text { Analysis }\end{array}$ & $\begin{array}{l}\text { 64 FR } 9560 \\
\text { February 26, } \\
1999\end{array}$ & 5.8 \\
\hline
\end{tabular}


Notwithstanding these variations, willingness to pay is the general basis for undertaking calculations. It is on the basis of this sort of analysis that the EPA compiled the following table, ${ }^{250}$ which can be taken as representative:

Table 4: Willingness-to-Pay Estimates (Mean Values)

\begin{tabular}{|c|c|}
\hline Health Endpoint & $\begin{array}{c}\text { Mean WTP Value per Incident } \\
(1990 \$)\end{array}$ \\
\hline \multicolumn{2}{|l|}{ Mortality } \\
\hline Life saved & $\$ 4.8$ million \\
\hline Life year extended & $\$ 120,000$ \\
\hline \multicolumn{2}{|l|}{ Hospital Admissions: } \\
\hline All Respiratory Illnesses, all ages & $\$ 12,700$ \\
\hline Pneumonia, age $<65$ & $\$ 13,400$ \\
\hline COPD, age $>65$ & $\$ 15,900$ \\
\hline Ischemic Heart Disease, age $<65$ & $\$ 20,600$ \\
\hline Congestive Heart Failure, age $>65$ & $\$ 16,600$ \\
\hline Emergency Visits for Asthma & $\$ 9,000$ \\
\hline Chronic Bronchitis & $\$ 260,000$ \\
\hline Upper Respiratory Symptoms & $\$ 19$ \\
\hline Lower Respiratory Symptoms & $\$ 12$ \\
\hline Acute Bronchitis & $\$ 45$ \\
\hline Acute Respiratory Symptoms (any of 19) & $\$ 18$ \\
\hline Asthma & $\$ 32$ \\
\hline Shortness of Breath & $\$ 5.30$ \\
\hline Sinusitis and Hay Fever & Not monetized \\
\hline Work Loss Days & $\$ 83$ \\
\hline \multicolumn{2}{|l|}{ Restricted Activity Days (RAD) } \\
\hline Minor RAD & $\$ 38$ \\
\hline Respiratory RAD & not monetized \\
\hline Worker Productivity & $\$ 1$ per worker per $10 \%$ change in ozone \\
\hline Visibility: residential & $\begin{array}{l}\$ 14 \text { per unit decrease in deciview per } \\
\text { household }\end{array}$ \\
\hline Recreational & $\begin{array}{l}\text { Range of } \$ 7.30 \text { to } \$ 11 \text { per unit decrease in } \\
\text { deciview per household (see U.S. EPA, 1997a) }\end{array}$ \\
\hline Household Soiling Damage & $\$ 2.50$ per household per $\mathrm{g} / \mathrm{m}^{3}$ \\
\hline
\end{tabular}

${ }^{250}$ Innovative Strategies Group, Environmental Protection Agency, Regulatory Impact Analysis, Ozone and Particulates (1998). 
To become intelligible, of course, these numbers must be combined with an assessment of the problems that would be averted with various approaches to regulation. As an example of such an assessment, consider the following:

Table 5: Proposed $\mathrm{PM}_{10}$ Standard (50/150 g/m³ ) 99th Percentile National Annual Health Incidence Reductions

Estimates are incremental to the current ozone and PM NAAQS: (year =2010)

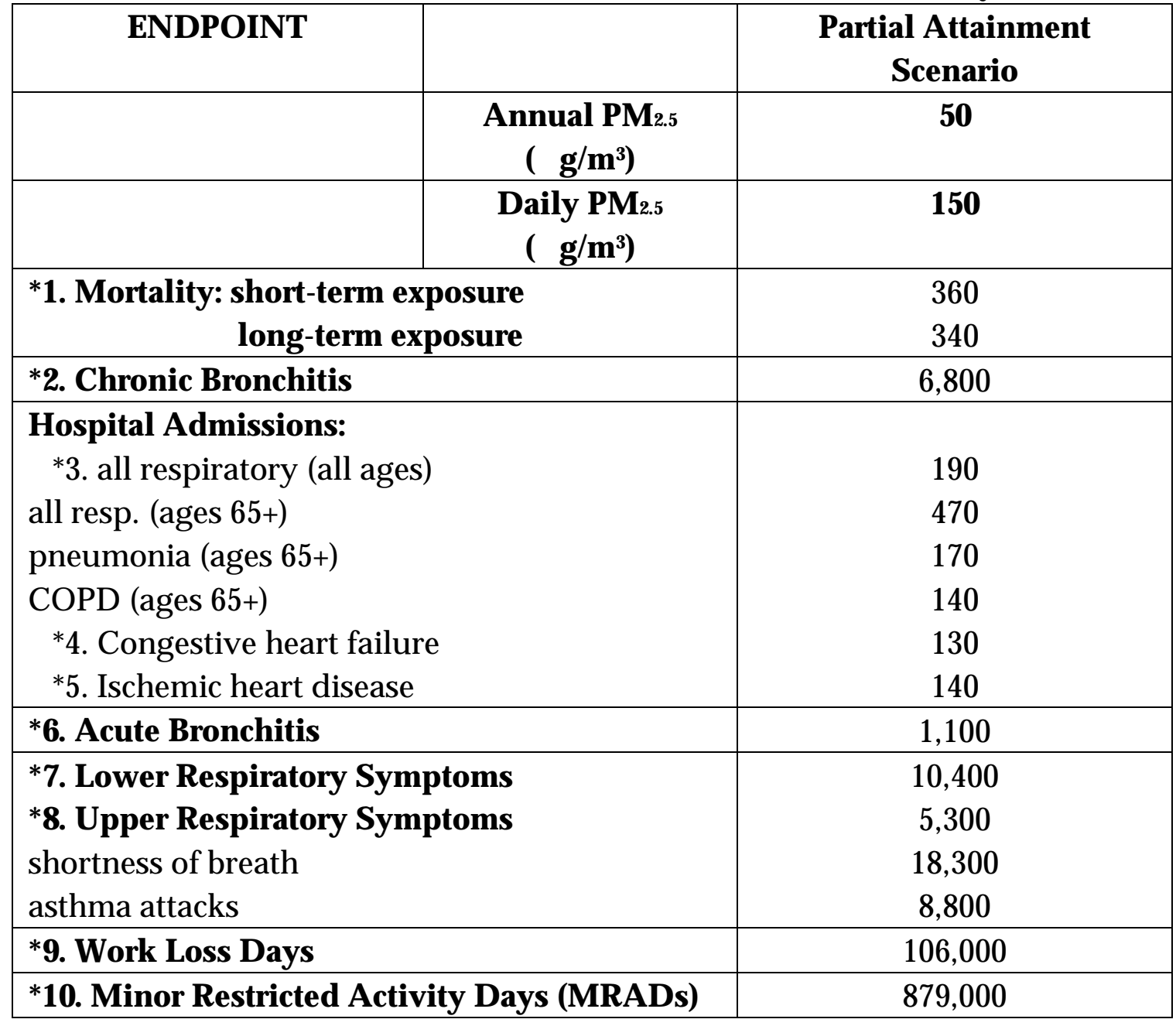

A simple exercise of multiplication, putting the two tables together, will generate monetized benefits, which can then be compared with monetized costs. Of course it is possible to challenge the numbers in both tables. Perhaps the agency has understated or overstated the number of lives saved or chronic bronchitis cases; perhaps the agency has overvalued or undervalued the dollar value of life or other health benefits. In fact evidence suggests that prospective 
estimates are bound to contain serious errors. The Office of Technology Assessment, asked in 1992 to evaluate the accuracy of OSHA's prospective estimates, found many mistakes. ${ }^{251}$ But the basic method increasingly dominates administrative practice.

2. Legal floors and ceilings. When would a given cost-benefit ratio be held to be unlawful? The simplest answer is that when the costs significantly exceed the benefits, when these are properly measured. A reasonable agency might begin with numbers near the middle of both market valuations ${ }^{252}$ and government valuations ${ }^{253}$ - in the case of a statistical life, somewhere between $\$ 3$ million and $\$ 7$ million. ${ }^{254}$ If an agency seeks to deviate from those numbers, it should explain why. The basic idea is that there should be a presumption in favor of adherence to the normal range, with an explanation of departures from the numbers thus indicated. And if the agency seeks to go forward with a regulation whose costs significantly exceed benefits, it should have to explain why it is doing that.

A legitimate risk in allowing departures is that the stated rationale will conceal an effort to placate powerful private groups not having a strong claim to

${ }^{251}$ See OMB, 1999 Report to Congress, at 40-43. A table, id. at 41, contains an illuminating summary:

Estimated Costs and Benefits of OSHA Rules: Prospective vs. Retrospective

\begin{tabular}{|l|l|l|l|}
\hline \multicolumn{1}{|c|}{ Regulation } & \multicolumn{1}{|c|}{$\begin{array}{c}\text { Year } \\
\text { Issued }\end{array}$} & \multicolumn{1}{|c|}{ Estimated Costs } & \multicolumn{1}{|c|}{ Estimated Benefits } \\
\hline Vinyl Chloride (a) & 1974 & Overestimated by a factor of four & Not clear \\
\hline Cotton Dust (a) & 1978 & Overestimated by a factor of three & $\begin{array}{l}\text { Overestimated by more than } \\
\text { a factor of two }\end{array}$ \\
\hline $\begin{array}{l}\text { Lead (Secondary } \\
\text { Smelters) }\end{array}$ & 1978 & $\begin{array}{l}\text { Capital costs significantly } \\
\text { underestimated }\end{array}$ & $\begin{array}{l}\text { Overestimated the } \\
\text { importance of engineering } \\
\text { controls in achieving benefits }\end{array}$ \\
\hline $\begin{array}{l}\text { Ethylene Oxide } \\
\text { (Hospitals) (a) }\end{array}$ & 1984 & About right & Not clear \\
\hline $\begin{array}{l}\text { Formaldehyde (Metal } \\
\text { Foundries) }\end{array}$ & 1987 & $\begin{array}{l}\text { Over by a factor of two (although } \\
\text { costs of engineering controls } \\
\text { considerably underestimated) }\end{array}$ & Not clear \\
\hline Grain Handling & 1987 & Not clear & Not clear \\
\hline PSDI Power Presses (b) & 1988 & Underestimated costs, overestimated benefits, or both \\
\hline Powered Platforms (b) & 1989 & Underestimated costs, overestimated benefits, or both \\
\hline
\end{tabular}

252 See W. Kip Viscusi, Risk Equity, 29 J Legal Stud (2000).

${ }^{253}$ See Stephen Breyer et al., Administrative Law and Regulatory Policy 30-31 (1999); Matthew Adler and Eric Posner, supra note.

${ }^{254}$ But see Robert Frank and Cass R. Sunstein, Cost-Benefit Analysis and Relative Position, U Chi

L Rev (forthcoming 2001) (urging inflation of these numbers). 
governmental assistance. ${ }^{255}$ Notwithstanding this risk, there are several possible grounds for making adjustments. For example, an agency might make a reasonable upward adjustment if it believes that children are largely at risk -perhaps because more life-years are at stake, perhaps because children are unable to protect themselves and hence have a special equitable claim to government resources. ${ }^{256} \mathrm{~A}$ downward adjustment would similarly be lawful if the agency finds that mostly old people are at risk, so that any extensions of lives would produce a low level of savings in terms of life-years. Or the agency might reasonably conclude that special attention should be given to risks faced by poor people or African-Americans, on the ground that existing injustice is compounded in a situation in which health and environmental dangers are thus concentrated.

Agencies should also be permitted to take into account the fact that people care about relative economic position, not only absolute economic position, and thus to adjust market valuations upwards. ${ }^{257}$ And the agency could reasonably employ "incidence analysis" to conclude that regulation should go forward notwithstanding the fact tha benefits exceed costs (see the reference to distributional considerations in OMB's "best practices" document, in the appendix). If, for example, the benefits are $\$ 800$ million, but enjoyed mostly by low-income workers, whereas the costs are $\$ 900$ million, but faced mostly by consumers generally, it seems reasonable for the agency to go forward, at least if Congress has not expressly precluded that judgment.

There is a larger point here. In addition to knowing the benefits and costs of regulation, it is necessary to know who bears those costs and enjoys those benefits, and also the particular nature of those costs and benefits. Suppose, for example, that an occupational safety and health regulation would have a total cost of $\$ 600$ million, and that the monetized benefits would be $\$ 400$ million (including, let us say, 40 lives saved per year, and hence \$200 million in monetized savings from fatalities averted). Is it clear that this regulation should not go forward? For various reasons it is not. If the people who are saved are children or teenagers, the uniform lives saved number might undervalue the relevant benefits. Equally important: What does the $\$ 600$ million mean, concretely? Does it mean that prices will increase, by a little, for many people?

\footnotetext{
255 See Viscusi, supra note (documenting abuses of this kind).

256 See the acknowledgement of the relevance of life-years in American Dental Association v. Martin, 984 F.2d 823, 827 (7th Cir. 1993).

${ }^{257}$ See Robert Frank and Cass R. Sunstein, Cost-Benefit Analysis and Relative Position, U Chi L Rev (forthcoming 2001).
} 
That cost might be worth incurring. So too if the consequence of the $\$ 600$ million expenditure would be a reduction in annual profits for companies that already make billions. Or does the cost mean that poor people will lose their jobs? An ideal cost-benefit analysis would tell us something about the incidence of both costs and benefits. It makes sense to say that the "bottom line" numbers will not be decisive when an incidence analysis shows that those numbers should be adjusted to take account of the identify of the winners and losers. Of course it is possible to think that we lack the tools to engage in a good incidence analysis, or that an assessment of distributional issues will be subject to interest-group manipulation, and hence that the "bottom line" numbers should be used for pragmatic reasons. ${ }^{258}$

While these points give agencies a degree of flexibility, they do not give them carte blanche, because they operate in limited domains, and because they come with a duty of reasoned explanation. This duty is procedural, but it is far more than that. In the Corrosion Proof Fittings case, for example, it is hard to see how the agency could have justified the extreme cost-benefit ratios that applied to certain bans on asbestos. ${ }^{259}$

3. The discount rate. Perhaps the most difficult issue here, from the theoretical point of view, involves the selection of the appropriate discount rate. How should the agency value future gains and losses? In terms of ultimate outcomes, the choice matters a great deal. If an agency chooses a discount rate of $2 \%$, the outcome will be very different from what it would be an agency chooses a discount rate of $10 \%$; the benefits calculation will shift dramatically as a result. If a human life is valued at $\$ 8$ million, and if an agency chooses a $10 \%$ discount rate, a life saved 100 years from now is worth only $\$ 581 .{ }^{260}$ "At a discount rate of five pecent, one death next year counts for more than a billion deaths in 500 years." ${ }^{261} \mathrm{OMB}$ suggests a 7\% discount rate (see Appendix); but this is highly controversial. A key question is therefore: What legal constraints should be imposed on the agency's choice?262

\footnotetext{
258 See Viscusi, Risk Equity, supra note.

259947 F.2d 1201 (5 $5^{\text {th }}$ Cir. 1991).

${ }^{260}$ See Michael Gerrard, Demons and Anegls in Hazardous Waste Regulation, 92 NW L Rev 706, 742-43 (1998).

${ }^{261}$ Derek Parfit, Reasons and Persons 357 (1984).

262 Valuable treatments include Richard Revesz, Environmental Regulation, Cost-Benefit Analysis, and the Discounting of Human Lives, 99 Col L Rev 941 (1999); Comment, Judicial Review of Discount Rates Used in Regulatory Cost-Benefit Analysis, 65 U Chi L Rev 1333 (1998).
} 
My basic conclusion is that it is much harder to untangle the theoretical issue than to identify the appropriate posture of reviewing courts. In this highly technical area, courts should adopt a posture of deference, requiring agencies only to produce a reasonable explanation for their choice and to show a degree of consistency. Part of the reason for deference is the extreme complexity of the underlying issues. Part of the reason is the risk that an aggressive judicial posture would contribute to the "ossification" of rulemaking 263 -- a particular problem in this setting, because any particular discount rate will be easy to challenge, with reasonable arguments suggesting that it is too low or too high. ${ }^{264}$ To understand these points, some details are in order.

Usually statutes are silent on the question of appropriate discount rate. In fact I have been unable to find any statute that specifies a discount rate for agencies to follow. On judicial review, the question will therefore involve a claim that the agency's choice is arbitrary. Here the national government shows strikingly (and inexplicably) variable practices. As noted, the Office of Management and Budget suggests a $7 \%$ discount rate, ${ }^{265}$ departing from a $10 \%$ rate in the 1980s. ${ }^{266}$ But agencies are not bound by OMB guidelines, and they have ranged from as low as 3\% (Food and Drug Administration, Department of Housing and Urban development ) to as high as 10\% (EPA). ${ }^{267}$ In fact the same agency sometimes endorses different discount rates for no apparent reason -with EPA, for example, selecting a 3\% rate for regulation of lead-based paint as compared to $7 \%$ for regulation of drinking water, and $10 \%$ rates, respectively, for regulation of emissions from locomotives. ${ }^{268}$ Here government practice seems extremely erratic.

From the purely economic standpoint, there are serious conundrums here. ${ }^{269}$ The impetus for discounting future effects stems from the judgment that in the context of money, discounting future benefits and losses is entirely rational, even simple: A dollar today is worth more than a dollar tomorrow. There are two reasons: investment value (or opportunity cost) and pure time

\footnotetext{
263 Thomas McGarity, Some Thoughts on "Deossifying” the Rulemaking Process, 1992 Duke LJ 1385.

${ }^{264}$ I am therefore disagreeing with the endorsement of "hard look" review in the excellent Comment, supra note.

265 See OMB, Benefit-Cost Analysis of Federal Programs, 57 Fed Reg at 53520 (1992).

266 See appendix for details; see also Revesz, supra note, at 950.

267 See Comment, supra note, at 1336-37.

268 Id. at 1337.

269 See id. at 1341-1350; see also Appendix for excerpts from OMB's own account.
} 
preference. ${ }^{270} \mathrm{~A}$ dollar today can be invested, and for this reason it is worth more than a dollar a year from now. An emphasis on the investment value of money yields a discount rate of roughly $5 \%-7 \%$. Quite apart from this point, people generally seem to have a preference for receiving money sooner rather than later. People value current consumption more than they value future consumption; for this reason alone, $\$ 1000$ is worth more today than it is in a decade. An inquiry into pure time preference produces discount rates of $1 \%-3 \%$. Though they lead to different numbers, both points justify discounting future income gains and losses.

So far, so good. The problem is that notwithstanding conventional wisdom among economists, these points are not easily taken to justify a discount rate for the nonmonetary benefits of regulation (see table 5 for an overview of such benefits). If a regulation will save ten lives this year, and ten years annually for the next ten years, it cannot plausibly be urged that the future savings are worth less than the current savings, on the ground that a current life saved can be immediately "invested." The point about investment value, or the opportunity cost of using capital, seems utterly irrelevant here. With time preference, things are less clear. Perhaps people would rather save ten lives today than ten lives in a decade. But it is unclear that this is so; and even if it is, what moral status would such a time preference have? Almost certainly it makes sense to say that it would be worse for you to lose your limb now than to lose it in ten years; in the latter case, you will have ten years of use of the limb. And probably it makes sense to say that agencies should attend to life-years saved, not only lives saved. But holding all this constant, the death of a thirty-five year old in 2004 does not seem worth more than the death of a thirty-five year old in 2044. And since different people are involved, the moral problem is serious: The preference of the chooser in 2002 is certainly relevant to determining that chooser's own fate, and the timing of risks that might come to fruition for that chooser; but the chooser's preference cannot easily be used to determine the fate of someone not yet born.

These points suggest that, as Richard Revesz suggests, it is important to distinguish two issues that go under the name of "discounting" and that have yet to be separated in administrative practice: (a) latent harms, in the form of exposures whose consequences will occur late in someone's lifetime; and (b) harms to future generations. ${ }^{271}$ It is reasonable to say that latent harms should

\footnotetext{
${ }^{270}$ Id. at 1341-46.

${ }^{271}$ As argued, convincingly, in Revesz, supra note.
} 
count for less than immediate ones, since they remove few years from people's lives. Some kind of discount rate is sensible here, although OMB's $7 \%$ figure is probably too high. ${ }^{272}$ The case of harms to future generations, or people not yet born, is altogether different, and in that case the usual grounds for discounting monetary benefits are quite inapplicable. For this reason some people think that no discounting is appropriate for the nonmonetary benefits of regulation. ${ }^{273} \mathrm{On}$ this view, a life-year saved is a life-year saved, and it does not matter, for purposes of valuation, when the saving occurs.

But there is a major objection to this way of proceeding: It would appear to require truly extraordinary sacrifices from the present for the sake of the (infinite) future. Perhaps the "failure to discount would leave all generations at a subsistence level of existence, because benefits would be postponed perpetually for the future." ${ }^{\prime 274}$ On the other hand, it is not clear that the assumption behind this objection is convincing. Technological and other advances made by the current generation benefit future generations as well, and hence impoverishment of the current generation would inevitably harm those who will come later. ${ }^{275}$ In any case there is a hard ethical question here - how much the current generation should suffer for the benefit of the future - and a judgment against discounting would not answer that question unless we were sure that as a matter of policy, we should be engaging in maximizing some aggregate welfare function. ${ }^{276}$ It is not at all clear that this form of maximization is the appropriate choice to make.

At this point it should be clear that these issues are exceedingly complex and that agencies asked to engage in cost-benefit analysis have no clear path to an appropriate choice of discount rate. My principal topic, however, is not regulatory policy, but the implementation of the cost-benefit default principles. In the face of the underlying conundrums, the most that a reviewing court can require is a rationale for the agency's choice that is both articulated and reasonable. There are several possibilities here, ${ }^{277}$ suggesting what courts should and should not do.

\footnotetext{
272 See id. at 981-87.

${ }^{273}$ Id. at 987-1009 (offering a qualified version of this view).

${ }^{274}$ See David Pearce and R. Kelly Turner, Economics of Natural Resources and the Environment 223-24 (1990).

275 Revesz, supra note, at 994.

276 Tyler Cowen and Derek Perfit, Against the Social Discount Rate, in Justice Between Age Groups and Generations 149 (Peter Laslett and James Fishkin eds. 1992).

277 For a good discussion, see Daniel Farber, Ecopragmatism (1999).
} 
- Courts should not require costs and benefits to have the same discount rate, at least not if costs are to be absorbed in terms of dollars and benefits will come in terms of fatalities and illnesses averted. It follows that in Corrosion Proof Fittings case, the court of appeals was quite wrong to tell EPA to produce an "apples-to-apples comparison, even if this entails discounting benefits of a non-monetary nature."278

- Courts should not simply defer to agency decisions as a "policy choice," as did one court in an unusually complex setting. ${ }^{279}$ What is necessary is some kind of explanation for the choice.

- Courts should acknowledge that good explanations can be given for a wide range of choices - between, say, a discount rate of $0 \%$ (for future generations, not latent harms) and 7\% (OMB's suggestion). So long as the agency gives a sensible rationale and departs from it only on the basis of articulated reasons, courts should respect the choice. The value judgments here can be reasonably disputed, and they should be made democratically, not judicially. It follows that in the context of discount rates, as elsewhere, the common law of cost-benefit analysis is to be developed at the administrative level, subject only to judicial review for reasonableness.

\section{Conclusion}

In this Article I have attempted to identify the cost-benefit default principles, to defend their use, and to explore their meaning for the future. In the face of statutory ambiguity, courts are now permitting agencies to refuse to regulate when a significant risk is not shown; to refuse to regulate beyond the point where regulation is not feasible; to consider costs; and to engage in a form of cost-benefit balancing. At their least intrusive, the cost-benefit default rules allow the agency to go in the suggested direction when the statute is unclear. At their most intrusive, the principles require the agency to act in the way they suggest unless Congress has unambiguously said otherwise.

I have argued on behalf of both the least and most intrusive version of the cost-benefit default rules, by suggesting that they are likely to give sense and rationality the benefit of the doubt. At the same time, I have urged that the argument on their behalf is presumptive only, and that in certain contexts, agencies have good reasons for embarking on a different course. The question is

\footnotetext{
${ }^{278}$ Corrosion Proof Fittings, supa note, 947 F.2d at 1218.

279880 F 2d at 465.
} 
whether agencies have been able to suffer a reasonable defense of their decision to that effect.

I have also attempted to set out some guidelines for the future, both under the cost-benefit default principles and under statutes that point in the same direction. It is necessary for agencies to particularize the idea of "significant" and "de minimis" risks through quantitative guidelines. A large point here is that the statistical probability of harm is not all that matters; the size of the exposed population is important as well. "Feasibility" is not an off-on switch, and here too agencies should specify what they understand the term to mean, beginning with the admittedly vague notion that massive dislocations would be both necessary and sufficient to show that regulation is not feasible. We have seen that with respect to valuation of life and health, market measures can provide a good start, from which agencies are entitled to make reasonable adjustments. We have also seen that the most difficult issue involves selection of the appropriate discount rate. Reviewing courts should not require agencies to apply the same discount rate to life and health that they apply to money; with respect to discounting, there are good reasons to distinguish money from other goods. The most that courts can do is to impose ceilings and floors on agency judgments, by requiring a good rationale for whatever discount rate is chosen.

The most general conclusion, signaled by the rise of the cost-benefit default principles, is that the nation is nearing the end of a "first generation" debate about whether to adopt a presumption in favor of cost-benefit balancing, and rapidly moving into a "second generation" debate about when the presumption is rebutted, and about what cost-benefit analysis specifically entails. If cost-benefit analysis is to be defended, it is not because of especially controversial judgments of value, but because of a belief that regulatory action should be judged largely in terms of its consequences. ${ }^{280}$ Suitably specified and understood, the cost-benefit default principles should be regarded, not as a technique for stalling desirable regulation, but as a pragmatic effort to ensure that regulation responds to serious problems rather than to trivial or imaginary ones. And if they are seen in these terms, the cost-benefit default principles operate not only a foundation for deterring regulation that promises to do less

\footnotetext{
280 Of course there is no way of assessing consequences, or even identifying them, that is entirely neutral on evaluative questions. What I mean to suggest is that agreed-upon understandings can do the necessary work here. See the outline of the track record of cost-benefit analysis at EPA, supra.
} 
good than harm, but also as a basis for producing regulatory action where an assessment of the consequences shows that regulation is desirable. ${ }^{281}$

${ }^{281}$ See the account, supra, of instances in which cost-benefit balancing spurred regulatory action. 


\section{Appendix: Excerpts from OMB Guidance on Cost-Benefit Analysis}

The following consists of excerpts from OMB's "best practices" guidelines for cost-benefit analysis. Because the understanding of cost-benefit analysis is so much better developed within OMB than within courts and the legal culture, it is worth attending, with some care, to $\mathrm{OMB}^{\prime}$ 's suggestions. I have challenged some of OMB's claims - especially on the appropriate discount rate - but there is no question that $\mathrm{OMB}$ has offered a helpful and thoughful treatment of many of the underlying problems.

\section{January 11, 1996}

Economic Analysis of Federal Regulations under Executive Order 12866

\section{ANALYSIS OF BENEFITS AND COSTS}

$\cdots$

\section{A. General Principles}

3. Discounting. One of the problems that arises in developing a benefitcost analysis is that the benefits and costs often occur in different time periods. When this occurs, it is not appropriate, when comparing benefits and costs, to simply add up the benefits and costs accruing over time. Discounting takes account of the fact that resources (goods or services) that are available in a given year are worth more than the identical resources available in a later year. One reason for this is that resources can be invested so as to return more resources later. In addition, people tend to be impatient and to prefer earlier consumption over later consumption.

(a) Basic considerations. Constant-dollar benefits and costs must be discounted to present values before benefits and costs in different years can be added together to determine overall net benefits. To obtain constant dollar estimates, benefit and cost streams in nominal dollars should be adjusted to correct for inflation. The basic guidance on discount rates for regulatory and other analyses is provided in OMB Circular A-94. The discount rate specified in that guidance is intended to be an approximation of the opportunity cost of capital, which is the before-tax rate of return to incremental private investment. The Circular A-94 rate, which was revised in 1992 based on an extensive review and public comment, reflects the rates of return on low yielding forms of capital, such as housing, as well as the higher rates of returns yielded by corporate 
capital. This average rate currently is estimated to be 7 percent in real terms (i.e., after adjusting for inflation). ...

Even those benefits and costs that are hard to quantify in monetary terms should be discounted.....

(b) Additional considerations. Modern research in economic theory has established a preferred model for discounting, sometimes referred to as the shadow price approach. The basic concept is that economic welfare is ultimately determined by consumption; investment affects welfare only to the extent that it affects current and future consumption. Thus, any effect that a government program has on public or private investment must be converted to an associated stream of effects on consumption before being discounted.

Converting investment-related benefits and costs to their consumptionequivalents as required by this approach involves calculating the "shadow price of capital." This shadow price reflects the present value of the future changes in consumption arising from a marginal change in investment, using the consumption rate of interest (also termed the rate of time preference) as the discount rate. ...

4. Treatment of Risk and Uncertainty. ... Often risks, benefits, and costs are measured imperfectly because key parameters are not known precisely; instead, the economic analysis must rely upon statistical probability distributions for the values of parameters. Both the inherent lack of certainty about the consequences of a potential hazard (for example, the odds of contracting cancer) and the lack of complete knowledge about parameter values that define risk relationships (for example, the relationship between presence of a carcinogen in the food supply and the rate of absorption of the carcinogen) should be considered.

(a) Risk assessment.... Data relating to effects that can be identified may be sketchy, incomplete, or subject to measurement error or statistical bias. Exposures and sensitivities to risks may vary considerably across the affected population. These difficulties can lead, for example, to a range of quantitative estimates of risk in health and ecological risk assessments that can span several orders of magnitude. Uncertainties in cost estimates also can be significant, in particular because of lack of experience with the adjustments that markets can 
make to reduce regulatory burdens, the difficulty of identifying and quantifying opportunity cost, and the potential for enhanced or retarded technical innovation. All of these concerns should be reflected in the uncertainties about outcomes that should be incorporated in the analysis.

The treatment of uncertainty in developing risk, benefit, and cost information also must be guided by the principles of full disclosure and transparency, as with other elements of an EA. Data, models, and their implications for risk assessment should be identified in the risk characterization.

In order for the EA to evaluate outcomes involving risks, risk assessments must provide some estimates of the probability distribution of risks with and without the regulation. Whenever it is possible to quantitatively characterize the probability distributions, some estimates of central tendency (e.g., mean and median) must be provided in addition to ranges, variances, specified low-end and high-end percentile estimates, and other characteristics of the distribution.

Overall risk estimates cannot be more precise than their most uncertain component. Thus, risk estimates should be reported in a way that reflects the degree of uncertainty present in order to prevent creating a false sense of precision. The accuracy with which quantitative estimates are reported must be supported by the quality of the data and models used. In all cases, the level of precision should be stated explicitly.

Overall uncertainty is typically a consequence of uncertainties about many different factors. Appropriate statistical techniques should be used to combine uncertainties about separate factors into an overall probability distribution for a risk....

Uncertainty may arise from a variety of fundamentally different sources, including lack of data, variability in populations or natural conditions, limitations in fundamental scientific knowledge (both social and natural) resulting in lack of knowledge about key relationships, or fundamental unpredictability of various phenomena. The nature of these different sources may suggest different approaches. For example, when uncertainty is due to lack of information, one policy alternative may be to defer action pending further study. One factor that may help determine whether further study is justifiable as a policy alternative is an evaluation of the potential benefits of the information relative to the resources needed to acquire it and the potential costs of delaying 
action. When uncertainty is due largely to observable variability in populations or natural conditions, one policy alternative may be to refine targeting, that is, to differentiate policies across key subgroups. Analysis of such policies should consider the incremental benefits of improved efficiency from targeting, any incremental costs of monitoring and enforcement, and changes in the distribution of benefits and costs....

7. Nonmonetized Benefits and Costs. Presentation of monetized benefits and costs is preferred where acceptable estimates are possible. However, monetization of some of the effects of regulations is often difficult if not impossible, and even the quantification of some effects may not be easy. Effects that cannot be fully monetized or otherwise quantified should be described. Those effects that can be quantified should be presented along with qualitative information to characterize effects that are not quantified.

Irrespective of the presentation of monetized benefits and costs, the EA should present available physical or other quantitative measures of the effects of the alternative actions to help decisionmakers understand the full effects of alternative actions. These include the magnitude, timing, and likelihood of impacts, plus other relevant dimensions (e.g., irreversibility and uniqueness). For instance, assume the effects of a water quality regulation include increases in fish populations and habitat over the affected stream segments and that it is not possible to monetize such effects. It would then be appropriate to describe the benefits in terms of stream miles of habitat improvement and increases in fish population by species (as well as to describe the timing and likelihood of such effects, etc.). ...

8. Distributional Effects and Equity. Those who bear the costs of a regulation and those who enjoy its benefits often are not the same people. The term "distributional effects" refers to the description of the net effects of a regulatory alternative across the population and economy, divided up in various ways (e.g., income groups, race, sex, industrial sector). Benefits and costs of a regulation may be distributed unevenly over time, perhaps spanning several generations. Distributional effects may also arise through "transfer payments" arising from a regulatory action. For example, the revenue collected through a fee, surcharge, or tax (in excess of the cost of any service provided) is a transfer payments.

Where distributive effects are thought to be important, the effects of various regulatory alternatives should be described quantitatively to the extent 
possible, including their magnitude, likelihood, and incidence of effects on particular groups. Agencies should be alert for situations in which regulatory alternatives result in significant changes in treatment or outcomes for different groups. Effects on the distribution of income that are transmitted through changes in market prices can be important, albeit sometimes difficult to assess. The EA should also present information on the streams of benefits and costs over time in order to provide a basis for judging intertemporal distributional consequences, particularly where intergenerational effects are concerned.

There are no generally accepted principles for determining when one distribution of net benefits is more equitable than another. Thus, the EA should be careful to describe distributional effects without judging their fairness. These descriptions should be broad, focusing on large groups with small effects per capita as well as on small groups experiencing large effects per capita. Equity issues not related to the distribution of policy effects should be noted when important and described quantitatively to the extent feasible.

B. Benefit Estimates

‥

The calculation of benefits (including benefits of risk reductions) should reflect the full probability distribution of potential consequences. For example, extreme safety or health results should be weighted, along with other possible outcomes, by estimates of their probability of occurrence based on the available evidence to estimate the expected result of a proposed regulation. To the extent possible, the probability distributions of benefits should be presented. Extreme estimates should be presented as complements to central tendency and other estimates. If fundamental scientific disagreement or lack of knowledge precludes construction of a scientifically defensible probability distribution, benefits should be described under plausible alternative assumptions, along with a characterization of the evidence underlying each alternative view. ...

1. General Considerations. The concept of "opportunity cost" is the appropriate construct for valuing both benefits and costs. The principle of "willingness-to-pay" captures the notion of opportunity cost by providing an aggregate measure of what individuals are willing to forgo to enjoy a particular benefit. Market transactions provide the richest data base for estimating benefits based on willingness-to-pay, as long as the goods and services affected by a potential regulation are traded in markets. It is more difficult to estimate benefits where market transactions are difficult to monitor or markets do not exist. 
Regulatory analysts in these cases need to develop appropriate proxies that simulate market exchange. Indeed, the analytical process of deriving benefit estimates by simulating markets may suggest alternative regulatory strategies that create such markets.

Either willingness-to-pay (WTP) or willingness-to-accept (WTA) can provide an appropriate measure of benefits, depending on the allocation of property rights. The common preference for WTP over WTA measures is based on the empirical difficulties in estimating the latter. ...

2. Principles for Valuing Benefits Directly Traded in Markets. Ordinarily, goods and services are to be valued at their market prices. However, in some instances, the market value of a good or service may not reflect its true value to society.

If a regulatory alternative involves changes in such a good or service, its monetary value for purposes of benefit-cost analysis should be derived using an estimate of its true value to society (often called its "shadow price"). For example, suppose a particular air pollutant damages crops. One of the benefits of controlling that pollutant will be the value of the crop saved as a result of the controls. That value would typically be determined by reference to the price of the crop. If, however, the price of that crop is held above the unregulated market equilibrium price by a government price-support program, an estimate based on the support price would overstate the value of the benefit of controlling the pollutant....

In other cases, market prices could understate social values, for example where production of a particular good also provides opportunities for improving basic knowledge.

3. Principles for Valuing Benefits That Are Indirectly Traded in Markets. .

A variety of methods have been developed for estimating indirectly traded benefits. Generally, these methods apply statistical techniques to distill from observable market transactions the portion of willingness-to-pay that can be attributed to the benefit in question. Examples include estimates of the value of environmental amenities derived from travel-cost studies, hedonic price models that measure differences or changes in the value of land, and statistical studies of occupational-risk premiums in wage rates. For all these methods, care 
is needed in designing protocols for reliably estimating benefits or in adapting the results of previous studies to new applications. The use of occupational-risk premiums can be a source of bias because the risks, when recognized, may be voluntarily rather than involuntarily assumed, and the sample of individuals upon which premium estimates are based may be skewed toward more risktolerant people.

Contingent-valuation methods have become increasingly common for estimating indirectly traded benefits, but the reliance of these methods on hypothetical scenarios and the complexities of the goods being valued by this technique raise issues about its accuracy in estimating willingness to pay compared to methods based on (indirect) revealed preferences. Accordingly, value estimates derived from contingent-valuation studies require greater analytical care than studies based on observable behavior. For example, the contingent valuation instrument must portray a realistic choice situation for respondents -- where the hypothetical choice situation corresponds closely with the policy context to which the estimates will be applied. The practice of contingent valuation is rapidly evolving, and agencies relying upon this tool for valuation should judge the reliability of their benefit estimates using this technique in light of advances in the state of the art.

\section{Principles and Methods for Valuing Goods That Are Not Traded}

Directly or Indirectly in Markets. Some types of goods, such as preserving environmental or cultural amenities apart from their use and direct enjoyment by people, are not traded directly or indirectly in markets. The practical obstacles to accurate measurement are similar to (but generally more severe than) those arising with respect to indirect benefits, principally because there are few or no related market transactions to provide data for willingness-to-pay estimates.

For many of these goods, particularly goods providing "nonuse" values, contingent-valuation methods may provide the only analytical approaches currently available for estimating values. The absence of observable and replicable behavior with respect to the good in question, combined with the complex and often unfamiliar nature of the goods being valued, argues for great care in the design and execution of surveys, rigorous analysis of the results, and a full characterization of the uncertainties in the estimates to meet best practices in the use of this method. 
(b) Fatality risks....

Reductions in fatality risks as a result of government action are best monetized according to the willingness-to-pay approach. . . . Another way of expressing reductions in fatality risks is in terms of the "value of statistical lifeyears extended" (VSLY). For example, if a regulation protected individuals whose average remaining life expectancy was 40 years, then a risk reduction of one fatality would be expressed as 40 life-years extended. This approach allows distinctions in risk-reduction measures based on their effects on longevity. However, this does not automatically mean that regulations with greater numbers of life-years extended will be favored over regulations with fewer numbers of life-years extended. VSL and VSLY ultimately depend on the willingness to pay for various forms of mortality risk reduction, not just longevity considerations.

To value reductions in more voluntarily incurred risks (e.g., those related to motorcycling without a helmet) that are "high," agencies should consider using lower values than those applied to reductions in involuntary risk. When a higher-risk option is chosen voluntarily, those who assume the risk may be more risk-tolerant, i.e., they may place a relatively lower value on avoiding risks. Empirical studies of risk premiums in higher-risk occupations suggest that reductions in risks for voluntarily assumed high risk jobs (e.g., above 10-4 annually) are valued less than equal risk reductions for lower-risk jobs. However, when occupational choices are limited, the occupational risks incurred may be more involuntary in nature.

\section{Cost Estimates ...}

As with benefit estimates, the calculation of costs should reflect the full probability distribution of potential consequences. Extreme values should be weighted, along with other possible outcomes, by estimates of their probability of occurrence based on the available evidence to estimate the expected result of a proposed regulation. If fundamental scientific disagreement or lack of knowledge precludes construction of a scientifically defensible probability distribution, costs should be described under plausible alternative assumptions, along with a characterization of the evidence underlying each alternative view. . 
Readers with comments should address them to:

\author{
Cass R. Sunstein \\ Karl N. Llewellyn Distinguished Service Professor \\ University of Chicago Law School \\ 1111 East 60th Street \\ Chicago, IL 60637
}


Chicago Working Papers in Law and Economics

(Second Series)

1. William M. Landes, Copyright Protection of Letters, Diaries and Other Unpublished Works: An Economic Approach (July 1991).

2. Richard A. Epstein, The Path to The T.J. Hooper: The Theory and History of Custom in the Law of Tort (August 1991).

3. Cass R. Sunstein, On Property and Constitutionalism (September 1991).

4. Richard A. Posner, Blackmail, Privacy, and Freedom of Contract (February 1992).

5. Randal C. Picker, Security Interests, Misbehavior, and Common Pools (February 1992).

6. Tomas J. Philipson \& Richard A. Posner, Optimal Regulation of AIDS (April 1992).

7. Douglas G. Baird, Revisiting Auctions in Chapter 11 (April 1992).

8. William M. Landes, Sequential versus Unitary Trials: An Economic Analysis (July 1992).

9. William M. Landes \& Richard A. Posner, The Influence of Economics on Law: A Quantitative Study (August 1992).

10. Alan O. Sykes, The Welfare Economics of Immigration Law: A Theoretical Survey With An Analysis of U.S. Policy (September 1992).

11. Douglas G. Baird, 1992 Katz Lecture: Reconstructing Contracts (November 1992).

12. Gary S. Becker, The Economic Way of Looking at Life (January 1993).

13. J. Mark Ramseyer, Credibly Committing to Efficiency Wages: Cotton Spinning Cartels in Imperial Japan (March 1993).

14. Cass R. Sunstein, Endogenous Preferences, Environmental Law (April 1993).

15. Richard A. Posner, What Do Judges and Justices Maximize? (The Same Thing Everyone Else Does) (April 1993).

16. Lucian Arye Bebchuk and Randal C. Picker, Bankruptcy Rules, Managerial Entrenchment, and Firm-Specific Human Capital (August 1993).

17. J. Mark Ramseyer, Explicit Reasons for Implicit Contracts: The Legal Logic to the Japanese Main Bank System (August 1993).

18. William M. Landes and Richard A. Posner, The Economics of Anticipatory Adjudication (September 1993).

19. Kenneth W. Dam, The Economic Underpinnings of Patent Law (September 1993).

20. Alan O. Sykes, An Introduction to Regression Analysis (October 1993).

21. Richard A. Epstein, The Ubiquity of the Benefit Principle (March 1994).

22. Randal C. Picker, An Introduction to Game Theory and the Law (June 1994).

23. William M. Landes, Counterclaims: An Economic Analysis (June 1994). 
24. J. Mark Ramseyer, The Market for Children: Evidence from Early Modern Japan (August 1994).

25. Robert H. Gertner and Geoffrey P. Miller, Settlement Escrows (August 1994).

26. Kenneth W. Dam, Some Economic Considerations in the Intellectual Property Protection of Software (August 1994).

27. Cass R. Sunstein, Rules and Rulelessness, (October 1994).

28. David Friedman, More Justice for Less Money: A Step Beyond Cimino (December 1994).

29. Daniel Shaviro, Budget Deficits and the Intergenerational Distribution of Lifetime Consumption (January 1995).

30. Douglas G. Baird, The Law and Economics of Contract Damages (February 1995).

31. Daniel Kessler, Thomas Meites, and Geoffrey P. Miller, Explaining Deviations from the Fifty Percent Rule: A Multimodal Approach to the Selection of Cases for Litigation (March 1995).

32. Geoffrey P. Miller, Das Kapital: Solvency Regulation of the American Business Enterprise (April 1995).

33. Richard Craswell, Freedom of Contract (August 1995).

34. J. Mark Ramseyer, Public Choice (November 1995).

35. Kenneth W. Dam, Intellectual Property in an Age of Software and Biotechnology (November 1995).

36. Cass R. Sunstein, Social Norms and Social Roles (January 1996).

37. J. Mark Ramseyer and Eric B. Rasmusen, Judicial Independence in Civil Law Regimes: Econometrics from Japan (January 1996).

38. Richard A. Epstein, Transaction Costs and Property Rights: Or Do Good Fences Make Good Neighbors? (March 1996).

39. Cass R. Sunstein, The Cost-Benefit State (May 1996).

40. William M. Landes and Richard A. Posner, The Economics of Legal Disputes Over the Ownership of Works of Art and Other Collectibles (July 1996).

41. John R. Lott, Jr. and David B. Mustard, Crime, Deterrence, and Right-toCarry Concealed Handguns (August 1996).

42. Cass R. Sunstein, Health-Health Tradeoffs (September 1996).

43. G. Baird, The Hidden Virtues of Chapter 11: An Overview of the Law and Economics of Financially Distressed Firms (March 1997).

44. Richard A. Posner, Community, Wealth, and Equality (March 1997).

45. William M. Landes, The Art of Law and Economics: An Autobiographical Essay (March 1997).

46. Cass R. Sunstein, Behavioral Analysis of Law (April 1997). 
47. John R. Lott, Jr. and Kermit Daniel, Term Limits and Electoral Competitiveness: Evidence from California's State Legislative Races (May 1997).

48. Randal C. Picker, Simple Games in a Complex World: A Generative Approach to the Adoption of Norms (June 1997).

49. Richard A. Epstein, Contracts Small and Contracts Large: Contract Law through the Lens of Laissez-Faire (August 1997).

50. Cass R. Sunstein, Daniel Kahneman, and David Schkade, Assessing Punitive Damages (with Notes on Cognition and Valuation in Law) (December 1997).

51. William M. Landes, Lawrence Lessig, and Michael E. Solimine, Judicial Influence: A Citation Analysis of Federal Courts of Appeals Judges (January 1998).

52. John R. Lott, Jr., A Simple Explanation for Why Campaign Expenditures are Increasing: The Government is Getting Bigger (February 1998).

53. Richard A. Posner, Values and Consequences: An Introduction to Economic Analysis of Law (March 1998).

54. Denise DiPasquale and Edward L. Glaeser, Incentives and Social Capital: Are Homeowners Better Citizens? (April 1998).

55. Christine Jolls, Cass R. Sunstein, and Richard Thaler, A Behavioral Approach to Law and Economics (May 1998).

56. John R. Lott, Jr., Does a Helping Hand Put Others At Risk?: Affirmative Action, Police Departments, and Crime (May 1998).

57. Cass R. Sunstein and Edna Ullmann-Margalit, Second-Order Decisions (June 1998).

58. Jonathan M. Karpoff and John R. Lott, Jr., Punitive Damages: Their Determinants, Effects on Firm Value, and the Impact of Supreme Court and Congressional Attempts to Limit Awards (July 1998).

59. Kenneth W. Dam, Self-Help in the Digital Jungle (August 1998).

60. John R. Lott, Jr., How Dramatically Did Women's Suffrage Change the Size and Scope of Government? (September 1998)

61. Kevin A. Kordana and Eric A. Posner, A Positive Theory of Chapter 11 (October 1998)

62. David A. Weisbach, Line Drawing, Doctrine, and Efficiency in the Tax Law (November 1998)

63. Jack L. Goldsmith and Eric A. Posner, A Theory of Customary International Law (November 1998)

64. John R. Lott, Jr., Public Schooling, Indoctrination, and Totalitarianism (December 1998)

65. Cass R. Sunstein, Private Broadcasters and the Public Interest: Notes Toward A "Third Way" (January 1999) 
66. Richard A. Posner, An Economic Approach to the Law of Evidence (February 1999)

67. Yannis Bakos, Erik Brynjolfsson, Douglas Lichtman, Shared Information Goods (February 1999)

68. Kenneth W. Dam, Intellectual Property and the Academic Enterprise (February 1999)

69. Gertrud M. Fremling and Richard A. Posner, Status Signaling and the Law, with Particular Application to Sexual Harassment (March 1999)

70. Cass R. Sunstein, Must Formalism Be Defended Empirically? (March 1999)

71. Jonathan M. Karpoff, John R. Lott, Jr., and Graeme Rankine, Environmental Violations, Legal Penalties, and Reputation Costs (March 1999)

72. Matthew D. Adler and Eric A. Posner, Rethinking Cost-Benefit Analysis (April 1999)

73. John R. Lott, Jr. and William M. Landes, Multiple Victim Public Shooting, Bombings, and Right-to-Carry Concealed Handgun Laws: Contrasting Private and Public Law Enforcement (April 1999)

74. Lisa Bernstein, The Questionable Empirical Basis of Article 2's Incorporation Strategy: A Preliminary Study (May 1999)

75. Richard A. Epstein, Deconstructing Privacy: and Putting It Back Together Again (May 1999)

76. William M. Landes, Winning the Art Lottery: The Economic Returns to the Ganz Collection (May 1999)

77. Cass R. Sunstein, David Schkade, and Daniel Kahneman, Do People Want Optimal Deterrence? (June 1999)

78. Tomas J. Philipson and Richard A. Posner, The Long-Run Growth in Obesity as a Function of Technological Change (June 1999)

79. David A. Weisbach, Ironing Out the Flat Tax (August 1999)

80. Eric A. Posner, A Theory of Contract Law under Conditions of Radical Judicial Error (August 1999)

81. David Schkade, Cass R. Sunstein, and Daniel Kahneman, Are Juries Less Erratic than Individuals? Deliberation, Polarization, and Punitive Damages (September 1999)

82. Cass R. Sunstein, Nondelegation Canons (September 1999)

83. Richard A. Posner, The Theory and Practice of Citations Analysis, with Special Reference to Law and Economics (September 1999)

84. Randal C. Picker, Regulating Network Industries: A Look at Intel (October 1999)

85. Cass R. Sunstein, Cognition and Cost-Benefit Analysis (October 1999) 
86. Douglas G. Baird and Edward R. Morrison, Optimal Timing and Legal Decisionmaking: The Case of the Liquidation Decision in Bankruptcy (October 1999)

87. Gertrud M. Fremling and Richard A. Posner, Market Signaling of Personal Characteristics (November 1999)

88. Matthew D. Adler and Eric A. Posner, Implementing Cost-Benefit Analysis When Preferences Are Distorted (November 1999)

89. Richard A. Posner, Orwell versus Huxley: Economics, Technology, Privacy, and Satire (November 1999)

90. David A. Weisbach, Should the Tax Law Require Current Accrual of Interest on Derivative Financial Instruments? (December 1999)

91. Cass R. Sunstein, The Law of Group Polarization (December 1999)

92. Eric A. Posner, Agency Models in Law and Economics (January 2000)

93. Karen Eggleston, Eric A. Posner, and Richard Zeckhauser, Simplicity and Complexity in Contracts (January 2000)

94. Douglas G. Baird and Robert K. Rasmussen, Boyd's Legacy and Blackstone's Ghost (February 2000)

95. David Schkade, Cass R. Sunstein, Daniel Kahneman, Deliberating about Dollars: The Severity Shift (February 2000)

96. Richard A. Posner and Eric B. Rasmusen, Creating and Enforcing Norms, with Special Reference to Sanctions (March 2000)

97. Douglas Lichtman, Property Rights in Emerging Platform Technologies (April 2000)

98. Cass R. Sunstein and Edna Ullmann-Margalit, Solidarity in Consumption (May 2000)

99. David A. Weisbach, An Economic Analysis of Anti-Tax Avoidance Laws (May 2000)

100. Cass R. Sunstein, Human Behavior and the Law of Work (June 2000)

101. William M. Landes and Richard A. Posner, Harmless Error (June 2000)

102. Robert H. Frank and Cass R. Sunstein, Cost-Benefit Analysis and Relative Position (August 2000)

103. Eric A. Posner, Law and the Emotions (September 2000)

104. Cass R. Sunstein, Cost-Benefit Default Principles (October 2000) 